Удк 338.465:621.31

\title{
МИРОВОЕ ПОТРЕБЛЕНИЕ ПЕРВИЧНЫХ ЭНЕРГОНОСИТЕЛЕЙ: ОСНОВНЫЕ ТЕНДЕНЦИИ ВО ВТОРОМ ДЕСЯТИЛЕТИИ ХХІ В.
}

\author{
Вазим Андрей Александрович1,2, \\ vazim@tpu.ru \\ 1 Томский государственный университет систем управления и радиоэлектроники, \\ Россия, 634050, г. Томск, пр. Ленина, 40 \\ ${ }^{2}$ Национальный исследовательский Томский политехнический университет, \\ Россия, 634050, г. Томск, пр. Ленина, 30
}

Вазим Андрей Александрович, кандидат экономических наук, доцент кафедры экономики Томского государственного университета систем управления и радиоэлектроники; доцент Школы инженерного предпринимательства Национального исследовательского Томского политехнического университета.

\begin{abstract}
Актуальность исследования определяется необходимостью повышения энергоэффективности и выполнением требований устойчивого развития. Цель работы: анализ тенденций по основным характеристикам на рынке энергоносителей: цене и объему потребления. Потребление выбрано по основным видам первичных энергоносителей: нефть, природный газ, ядерное топливо, возобновляемые источники энергии, гидроэлектроэнергия, каменный уголь. Анализ и прогноз цен проводятся только для нефти марки «Брент». Также необходимо изучить влияние требований устойчивого развития на потребление энергоносителей по макрорегионам: Северная Америка, Южная Америка и Карибы, Азиатско-Тихоокеанский регион, страны СНГ, Средний Восток, Европейский регион, Африка. Методы: прогнозная экстраполящия, основанная на анализе трендов, определяющих на уровне макрорегионов готовность к отказу от устаревших и развитию современных видов первичных энергоносителей; метод аналогии при построении циклической модели цен на нефть. Результаты. Выделены и охарактеризованы четыре цикла динамики цен на нефть в первые два десятилетия XXI в. Спрогнозированы два варианта ценовых уровней на 2020-2021 г2. Дана характеристика основным тенденциям 8 потреблении первичных энергоносителей отдельно по каждому их виду и каждому региону мира.
\end{abstract}

Ключевые слова: Мировая энергетика, прогнозирование цен на нефть, первичные энергоносители, нетрадиционные источники нефти, возобновляемые источники энергии, устойчивое развитие.

Развитие энергетики в XXI в. определяется не только рыночными требованиями (цены, условия поставок и т. д.), но и государственными и межгосударственными нормативными актами. Примером такого регулирования выступает законодательство в рамках требований устойчивого развития. Следует отметить, что эти требования на межгосударственном уровне являются рекомендательными для национального законодательства, поэтому одни страны готовы добровольно принимать ограничения в использовании невозобновляемых природных ресурсов, а другие - отказываются менять свое законодательство из-за важности сохранения темпов экономического роста.

\section{Энергосбережение и выполнение требований устойчивого развития}

Современные требования устойчивого развития наиболее четко прописаны в документах ООН и касаются всех стран планеты. В целом ООН определено 17 целей в области устойчивого развития (далее - ЦУР) [1]. Для данной статьи мы выбрали две цели: 1) 
цель 7 «Обеспечение всеобщего доступа к недорогим, надежным, устойчивым и современным источникам энергии для всех» [2]; 2) цель 12 «Обеспечение перехода к рациональным моделям потребления и производства» [3].

Достижение ЦУР 7 предполагается по следующим направлениям: разработка нетрадиционных источников нефти и газа, развитие технологий получения энергии из «возобновляемых источников» (далее - ВИЭ), развитие атомной энергетики. Ещё не везде население обеспечено доступом к электричеству. В отчете The Energy Progress Report - 2020 указывается, что к 2018 г. в Центральной и Южной Азии остаются не обеспеченными электроэнергией 8 \% населения, а в странах Африки к югу от Сахары - до 53\% [4]. Достижение ЦУР 12 предполагается по следующим направлениям: повышение доступности водных ресурсов, развитие энергетики, повышение доступности продовольствия. При этом направления ЦУР 12 связаны друг с другом: доступность чистой пресной воды повышает потенциал выращивания продовольствия; излишки некоторых продуктов могут быть использованы для получения автомобильного топлива в виде спирта; развитие энергетики позволит очищать сточные воды и разрабатывать новые источники чистой пресной воды. Повышение эффективности использования ресурсов также означает уменьшение отходов. Объем только одной категории отходов, муниципальных отходов, по прогнозам, вырастет с 3,5 млн тонн в день в 2010 году до более чем 6 млн тонн в день к 2025 г., утроившись до 11 млн тонн в день к 2100 г., что означает рост затрат на утилизацию и усиление воздействия на окружающую среду и здоровье человека. Сжигание отходов вызывает озабоченность по поводу загрязнения воздуха, в то время как на свалках происходит утечка метана - мощного парникового газа, который усугубляет изменение климата [5].

Фактологической основой статьи служат отчеты ООН, ОЭСР, Международного энергетического агентства, Института энергетических исследований, ОПЕК и крупнейших компаний (Бритиш Петролеум, Экссон Мобил и др.).

В отчётах Международного энергетического агентства (IEA) указывается, что в 1973-2011 г. за счёт повышения энергоэффективности было обеспечено более половины прироста потребности человечества в энергетических услугах. В эти годы мировой ВВП вырос в 3,3 раза, а потребление первичной энергии - в 2,1 раза. Если бы энергоемкость ВВП оставалась на уровне 1973 г., то прирост потребления энергии составил бы 14,1 вместо 7 млрд тнэ. Следовательно, за счет повышения энергоэффективности было обеспечено более половины прироста - 7,1 млрд тнэ [6].

На рост эффективности использования ископаемого топлива указывают и специалисты компании Бритиш Петролеум: «В течение многих лет эффективность стандартной тепловой электростанции предполагалась равной $38 \%$. Однако в действительности средняя мировая эффективность использования энергии на основе ископаемого топлива со временем выросла с примерно $36 \%$ в 2000 г. до более чем $40 \%$ сегодня. Более того, учитывая гораздо более высокий КПД самой современной электростанции (например, тепловая эффективность современной газотурбинной установки превышает 55 \%), ожидается, что в будущем средний мировой показатель увеличится» [7].

На основании исследований институтов различных стран Международное энергетическое агентство разработало рекомендации по вопросам политики энергоэффективности. При этом экономия энергии к 2030 г. в результате выполнения рекомендаций ожидается на уровне 92 ЭДж $\left(92 \cdot 10^{18}\right.$ Дж). В структуре экономии энергии это выглядит следующим образом: здания - $34 \%$, оборудование - $13 \%$, освещение - $10 \%$, транспорт $24 \%$, промышленность - $20 \%$ [8]. 
В отчете Международного агентства по возобновляемой энергии (The International Renewable Energy Agency (далее - IRENA)) выделяются два прогнозных сценария устойчивого развития с возможной структурной перестройкой потребления первичной энергии до 2050 г.: Плановый энергетический сценарий (PES) и Сценарий энергетической трансформации (TES). В табл.1 представлены основные параметры их прогнозов [9].

Таблица 1. Два сценария выбросов углекислоты и потребления энергетических ресурсов к 2030 и 2050 г2.

Table 1. Planned energy scenario and the transforming energy scenario evolution of energy-related $\mathrm{CO}_{2}$ emissions and nature of energy in 2030 and 2050

\begin{tabular}{|c|c|c|c|c|c|c|}
\hline \multirow{2}{*}{$\begin{array}{l}\text { Показатель } \\
\text { Index }\end{array}$} & \multicolumn{2}{|c|}{$\begin{array}{l}\text { Предыстория } \\
\text { Background }\end{array}$} & \multicolumn{2}{|c|}{$\begin{array}{c}\text { Сценарий PES } \\
\text { PES script }\end{array}$} & \multicolumn{2}{|c|}{$\begin{array}{l}\text { Сценарий TES } \\
\text { TES script }\end{array}$} \\
\hline & 2015 & 2019 & 2030 & 2050 & 2030 & 2050 \\
\hline $\begin{array}{l}\text { Эмиссия } \mathrm{CO}_{2} \text { электроэнергетикой, Гт } \\
\mathrm{CO}_{2} \text { emissions by the electric power industry, Gt }\end{array}$ & 32 & 34 & 35 & 33 & 25 & 9,5 \\
\hline $\begin{array}{l}\text { Потребление первичной энергии, ЭДж } \\
\text { Primary energy consumption, EJ }\end{array}$ & 571 & 599 & 647 & 710 & 556 & 538 \\
\hline $\begin{array}{l}\text { Потребление жидкого топлива, ЭДж } \\
\text { Liquid fuel consumption, EJ }\end{array}$ & 468 & 485 & 450 & 440 & 313 & 130 \\
\hline $\begin{array}{l}\text { Доля ВИЭ, \% } \\
\text { Share of RES, \% }\end{array}$ & 9,5 & 10,5 & 17 & 25 & 28 & 66 \\
\hline $\begin{array}{l}\text { Коэффициент повышения энергоэффективности (\%, год) } \\
\text { Energy efficiency improvement rate }(\%, \text { year })\end{array}$ & \multicolumn{2}{|c|}{1,8} & 2,4 & 2,6 & 3,6 & 3,2 \\
\hline $\begin{array}{l}\text { Удельный вес электроэнергии в потребляемой энергии, \% } \\
\text { Specific weight of electricity in consumed energy, \% }\end{array}$ & 19 & 20 & 24 & 30 & 29 & 49 \\
\hline $\begin{array}{l}\text { Электромобили, млн шт. } \\
\text { Electric vehicles, million units }\end{array}$ & 1,2 & 7,9 & 269 & 627 & 379 & 1109 \\
\hline $\begin{array}{l}\text { Тепловые помпы, млн шт. } \\
\text { Heat pumps, million units }\end{array}$ & 20 & 38 & 63 & 119 & 155 & 334 \\
\hline
\end{tabular}

В этой таблице мы видим, что сценарий энергетической трансформации более радикально толкает развитие мировой экономики к устойчивому развитию, чем плановый энергетический сценарий. Так, по сценарию TES к 2050 г. выбросы углекислого газа сокращаются в 3,5 раза в сравнении с PES. Последний сценарий предполагает, что человечество сможет удержаться на прежнем уровне выбросов. Потребление первичной энергии TES меньше на четверть, чем TES, жидкого топлива - ниже больше чем в три раза, а доля ВИЭ - выше в 2,6 раза. Выпуск автомобилей без использования жидкого топлива больше почти в два раза. Использование тепловых помп (в т. ч. кондиционеров) для уменьшения рассеяния тепла больше почти в три раза.

В нашей стране по заказу Правительства РФ и совместно с Академией наук РФ подготовлена Энергетическая стратегия России на период до 2035 г. В ней значительное внимание уделяется проблемам повышения энергоэффективности. Так, к 2035 г. данный нормативный акт предполагает снижение уровня электроемкости ВВП на 40 \%, а энергоемкости - на 50 \% (от уровня 2010 г.) [10]. Основные меры государственной энергетической политики в этой сфере предполагают развитие механизма энергосервисных контрактов; механизмов налогового стимулирования для приобретения энергоэффективного оборудования; предоставление государственных гарантий по кредитам на реализацию проектов в области энергоэффективности и энергосбережения [11].

Таким образом, требования устойчивого развития становятся фоном в игре рыночных сил и отдельных государств в перетягивании прибылей и условий хозяйствования. Примером такой игры могут служить цены на нефть и другое ископаемое топливо. Если 
ранжировать энергоносители по степени различных корпоративных или государственных ограничений в их ценообразовании, то самой рыночной является цена на нефть. Нефть может выступать как энергоноситель, так и как сырье для химической промышленности. Природный газ также может выступать как энергоноситель и сырье для нефтегазохимии. Однако цены на природный газ, продающийся на бирже, затрагивают незначительную долю покупаемого газа. В основном природный газ продается в рамках долгосрочных контрактов по схеме «бери или плати», когда определяется минимальная величина платежей за контрактуемый газ. В таких условиях газ лучше получить от поставщика и потом продать на бирже по любой цене для снижения убытков. Если же возникнет необходимость купить газа больше, чем по контракту, то такая потребность чаще возникает у многих покупателей сразу. В результате обнаруживается дефицит газа, который не может быть покрыт несколько месяцев. В отличие от рынка природного газа, ориентированного на трубопроводные поставки, рынок нефти способен в течение нескольких дней удовлетворить заявку благодаря наличию большого танкерного флота во всех морях мира. Электроэнергия (ядерная, гидроэлектроэнергия, от возобновляемых источников энергии) хранению поддается слабо, применяется передача электроэнергии на значительные расстояния по линиям электропередач. Потребление электроэнергии сильно регулируется корпоративными контрактами и государствами. Рынок угля больше ориентирован на получение электроэнергии и как топливо, но не на рынок химической продукции. А это означает, что рынок угля объективно меньше рынка жидких углеводородов (грубо говоря - нефти).

При изучении динамики цен на нефть использовались данные только по сорту Брент, т. к. он чаще представлен на рынке и меньше всего связан регулированием. Иначе говоря, сорт нефти марки «Брент» - наиболее рыночный сорт нефти.

\section{Падение цен на нефть - закономерный итог развития энергетической отрасли?}

Падение цен на нефть весной этого года не было первым в этом веке. Особенность данного спада в том, что он произошёл на фоне стимулирования развития возобновляемых источников энергии и нетрадиционных источников углеводородов, таких как сланцевая нефть. Ещё одно отличие - в глубине падения. В этом веке первый спад цен произошёл во втором полугодии 2008 г. со 140,44 до 40,11 долл. США (меньше в 3,5 раза). Он случился после длительного периода «процветания» на рынке нефти и напомнил о кризисе 1929 г., завершившем период «просперити» - послевоенный рост благополучия. Второй спад произошёл во второй половине 2014 г. со 112,5 до 49,15 долл. США (или в 2,3 раза). Этот спад объяснялся прекращением программы «денежного расширения». Третий спад начался через три месяца после второго, но длился почти год - до января 2016 г. Поэтому его следует отделить от второго спада. Его глубина была больше, чем у предыдущих падений - до 34,73 долл. США. Спад 2018 г. был меньше и по интенсивности (в 1,53 раза), и по глубине (нижняя цена - 53,8 долл. США). С предыдущими спадами его роднит время кризиса - осень. Однако его можно назвать промежуточным спадом, т. к. его величина (около 30 долл. США) похожа на величину промежуточного спада второй волны подъема цен с февраля по июнь 2012 г.

Нынешний кризис наступил весной: значительное падение (2,6 раза) с 66,0 до 25,27 долл. США. 20 апреля 2020 г. наблюдались даже отрицательные цены на нефть, что является экономическим нонсенсом. Кроме того, отсутствовал длительный период процветания на рынке нефти, как это было ранее: перед первым кризисом - 3,5 года (январь 2004 г. по июнь 2008 г.), перед вторым - 4,5 года (с января 2009 г. по июнь 2014 г.). Достаточно было двенадцати месяцев 2019 г., чтобы случился обвал котировок на рынке 
нефти. Второй квартал года показал обнадеживающие результаты, но оставил открытыми два вопроса: каковы причины падения цен на энергоносители и насколько долгим будет подъём цен?

Подъём цен объективно обусловлен ростом потребления энергоресурсов (в том числе, и нефти) вследствие роста промышленности, сельского хозяйства, строительства и объёма услуг. Другим фактором, объективно повышающим цены, является истощение месторождений полезных ископаемых. Кроме того, выполнение требований устойчивого развития может являться формой истощения полезных ископаемых и толкать цены вверх.

Падение цен вызывается прежде всего экономией - сокращением потребления относительно «дорогих» ресурсов. Долгосрочные факторы снижения цен - влияние внедрения новых технологий в энергосбережение, внедрения технологий добычи энергоресурсов из «нетрадиционных» источников (побережья, шельф Арктики, сланцевая нефть и т. д.), а также внедрения технологий получения энергии из «возобновляемых источников».

На рис. 1 показан график текущих цен на нефть с января 2000 г. по июль 2020 г. [12]. Каждая точка на графике - это среднемесячная цена на нефть сорта Брент. Квадратами обозначены пиковые значения цены, кружками обозначены узловые позиции в смене трендов цены на нефть.

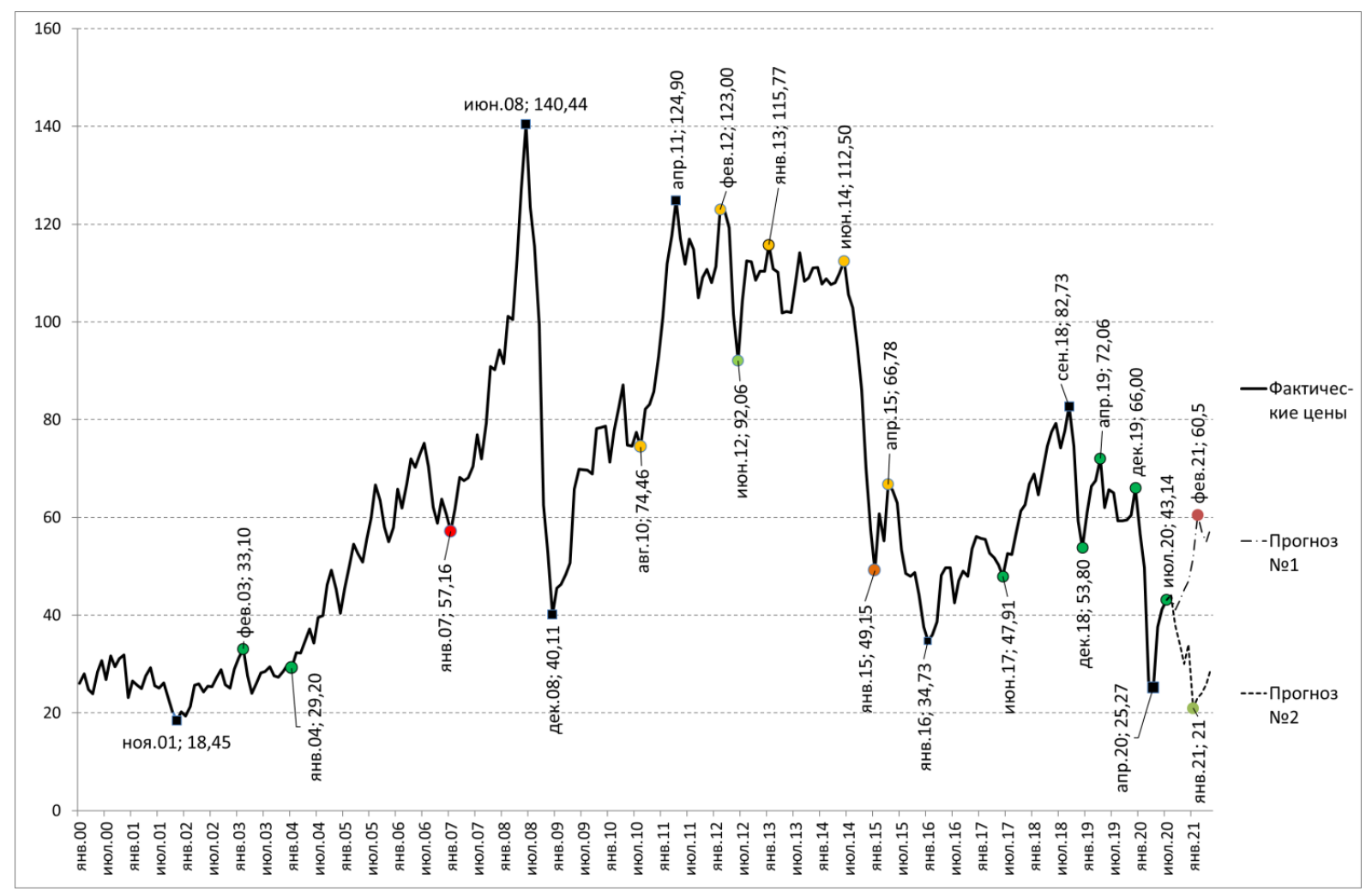

Puc. 1. График текущих цен на нефть с января 2000 по июль 2020 г., долл. за баррель

Fig. 1. Crude oil prices monthly January 2000 to July 2020

На рисунке показано, что до января 2004 г. наблюдаются колебания цен на нефть в узком коридоре - от 20 до 35 долл. США за баррель. С января 2004 г. начался рост цен. 
Следующий период - с января 2007 по июнь 2008 г. мы наблюдаем рост цен по экспоненте. Такой рост цен мог вызваться несколькими совпавшими причинами, которые в рамках статьи мы не будем рассматривать. Укажем только, что такая динамика цен подстегнула инвестиции как в новые источники углеводородов (сланцевая нефть, добыча на шельфе и т. д.), так и в альтернативную энергетику (солнечную, ветряную).

Резкое падение цены на нефть с июня по декабрь 2008 г. поставило под сомнение достоверность гипотезы о таком кризисе в отрасли, который приведет к изменению энергетической структуры. Ведь еще пять лет назад нефтяная энергетика могла существовать при более низких ценах, а развитие альтернативной энергетики делало первые шаги. Очередной рост цен на нефть до апреля 2011 г. прибавил уверенности тем, кто заявлял об исчерпании прежних нефтегазовых ресурсов. С 2011 до середины 2014 г. мейнстримом в публикациях по этой тематике были изучение и характеристика текущего кризиса, что служит знаком того, что изменилась структура потребления первичной энергии в пользу новых источников.

Однако затем последовал спад цен: сначала в январе 2015 г. до 49,15, а затем в январе 2016 г. до 34,73 долл. за баррель. Динамика цен на нефть с января 2016 по апрель 2020 г. напоминает колебания цен в период с августа 2010 по январь 2015 г., но на 40 долл. США дешевле. Причиной такой динамики цикла, вероятно, являются разработка новых источников углеводородов и развитие альтернативной энергетики.

Поэтому мы можем построить два возможных прогноза: условно оптимистический (Прогноз № 1) и пессимистический (Прогноз № 2). Прогноз № 1 опирается на идею, что перестанут действовать факторы, давящие цены на нефть вниз. Например, начнётся сокращение добычи «нетрадиционных» нефти и газа. В этом случае повторится ситуация восьмилетней давности, когда падение цен началось в феврале 2012 г., а закончилось в июне того же года с той разницей, что последнее падение цен началось и закончилось на два месяца раньше. В тот период цены почти подтянулись к уровню годичной давности: 115,77 долл. США в январе 2013 г. против 123,00 долл. США в феврале 2012 г. Смещение кризиса на два месяца может быть объяснено политическими мотивами: борьбой между Россией, Саудовской Аравией и США на рынке углеводородов [13]. При согласовании позиций заинтересованных сторон цикл войдет в свою нормальную фазу. На этом основании к февралю 2021 г. можно ожидать цены выше 60 долл. США.

Прогноз № 2 опирается на два предположения. Во-первых, возможно предположить нарушение договоренностей между Россией, США и Саудовской Аравией, если какая-либо сторона решит их нарушить. Во-вторых, влияние «нетрадиционных» нефти и газа и альтернативной энергетики может не только понизить максимумы цен, но и сократить продолжительность цикла. И тогда падение цен декабря 2019 - апреля 2020 гг. получает сходство с падением цен июня 2014 - января 2015 гг. В этом случае, следует ждать нового падения цен спустя три-четыре месяца после достижения минимума. Три-четыре месяца после апреля - это июнь и июль. Поэтому в ближайшие месяцы может начаться новый виток спада цен с дальнейшим подъемом не выше 35 долл. США за баррель (как было до января 2004 г.).

Такой прогноз мог бы выглядеть малореалистичным, если бы не интенсивное развитие факторов, ограничивающих потребление «традиционной» нефти. Об этом говорится в совместном отчете Института энергетических исследований Российской академии наук и Центра энергетики Московской школы управления «Сколково». В этом отчете указывается, что мировое потребление нефтепродуктов к 2040 г. может снизиться на $13 \%$, доля возобновляемых источников энергии вырастет до $25 \%$. В отчете отмечены три сценария: консервативный, инновационный и энергопереход. Во всех этих 
сценариях предполагается повышение цен на нефть от нынешних цен: консервативный прогноз - 106 долл. за баррель, инновационный - 76 и энергопереход - 60 долл. США за баррель. Другими словами, консервативный прогноз дает почти двукратное превышение цен на нефть, чем менее благодушный к нефтеэкспортирующим странам прогноз энергоперехода [14]. Поэтому мы можем свой прогноз строить не на абсолютных цифрах, которые могут быть обусловлены еще и инфляцией, а на относительных, характеризующих качественные изменения в мировой экономике. Кроме того, прогноз низких цен на нефть (от 30 до 40 долл. США за баррель Брент) до середины июля 2021 г. дают и эксперты Trading Economics, занимающиеся предоставлением биржевой информации [15]. В отличие от экспертов Сколково, опирающихся на долгосрочные тенденции, эксперты Trading Economics используют методы технического анализа данных. Технический анализ удобнее использовать на коротких периодах (промежутках) исследования. Мы в своей статье стремились использовать методы факторного анализа, который чаще применяется для долгосрочных прогнозов. Тем не менее пришли к похожим выводам в прогнозах на ближайшее будущее. Обоснуем этот тезис ниже.

В условиях низкой эластичности спроса на нефть ограничение потребления приводит к значительному падению цены. Если бы предложение нефти было эластичным, то сокращение или расширение объема нефти на рынке могло действовать в такт спросу и не было бы таких колебаний цен, какие мы видели в эти два десятилетия. Поэтому низкая эластичность предложения нефти скорее приведёт к банкротству отдельных нефтедобывающих компаний (или государств), чем к сокращению добычи большинством из них. А вот если правительства могут помочь своим нефтедобывающим компаниям в виде отсрочек налогов или кредитами, то эти компании могут предлагать нефть по любой цене, позволяющей продолжать деятельность. В условиях спада экономики из-за карантинных ограничений нефтедобывающие страны могут захотеть стимулировать свою экономику с помощью экспорта нефти по любой, сколь угодно низкой цене. Резюмируем: прогноз № 2 о колебаниях цен в диапазоне 20-35 долл. США реалистичен в равной степени с оптимистичным прогнозом № 1. Такие низкие цены означают повышенные риски для реализации Государственной программы Российской Федерации «Развитие энергетики» [16].

Далее подробнее рассмотрим динамику роста производства новых источников углеводородов и альтернативной энергетики, ограничивающих потребление «традиционных» нефти и газа.

\section{Нетрадиционные источники нефти}

К нетрадиционным источникам чаще всего относят следующие виды нефти: сланцевая нефть, нефть низкопроницаемых пород, плотная нефть и нефть из битуминозных песков. Совокупный потенциал мировой добычи нефти сланцевых плеев оценивается ИНЭИ РАН к 2020 г. в 84-208 млн т и к 2035 году - в 150-418 млн т, порядка 10 \% от суммарного объема предложения всех жидких видов топлив. В 2011 г. в мире добыли около 40 млн т нефти из этих источников [17]. Прогнозная оценка технически извлекаемых запасов сланцевой нефти по странам составляет следующую величину: Россия - 75, США - 58, КНР - 32, Аргентина - 27, Ливия - 26, Австралия - 18, Венесуэла и Мексика - 13, Канада и Пакистан - 9 млрд баррелей [18].

Чтобы наглядно увидеть влияние данных источников, рассмотрим табл. 1 и рис. 2 [19]. На них указаны величины балансов потребления (добыча минус потребление) нефти по странам и регионам, в процентах от размера потребления нефти. Сумма процентов не равна нулю из-за принятой в Бритиш петролеум методологии. 
На этом рисунке мы видим относительно стабильные величины баланса для всех макрорегионов, кроме Северной Америки и Азиатско-Тихоокеанского региона. В Северной Америке наблюдается рост добычи нефти и появление самообеспеченности: от зависимости в импорте в 12,7-13,1 \% в 2004-2005 гг. до экспорта нефти 1,1 \% в 2019 г. Рост добычи произошёл практически только за счет «нетрадиционных» нефти и газа. Азиатско-Тихоокеанский регион повысил свою долю в мировом импорте нефти на $9 \%$ в связи с экономическим ростом.

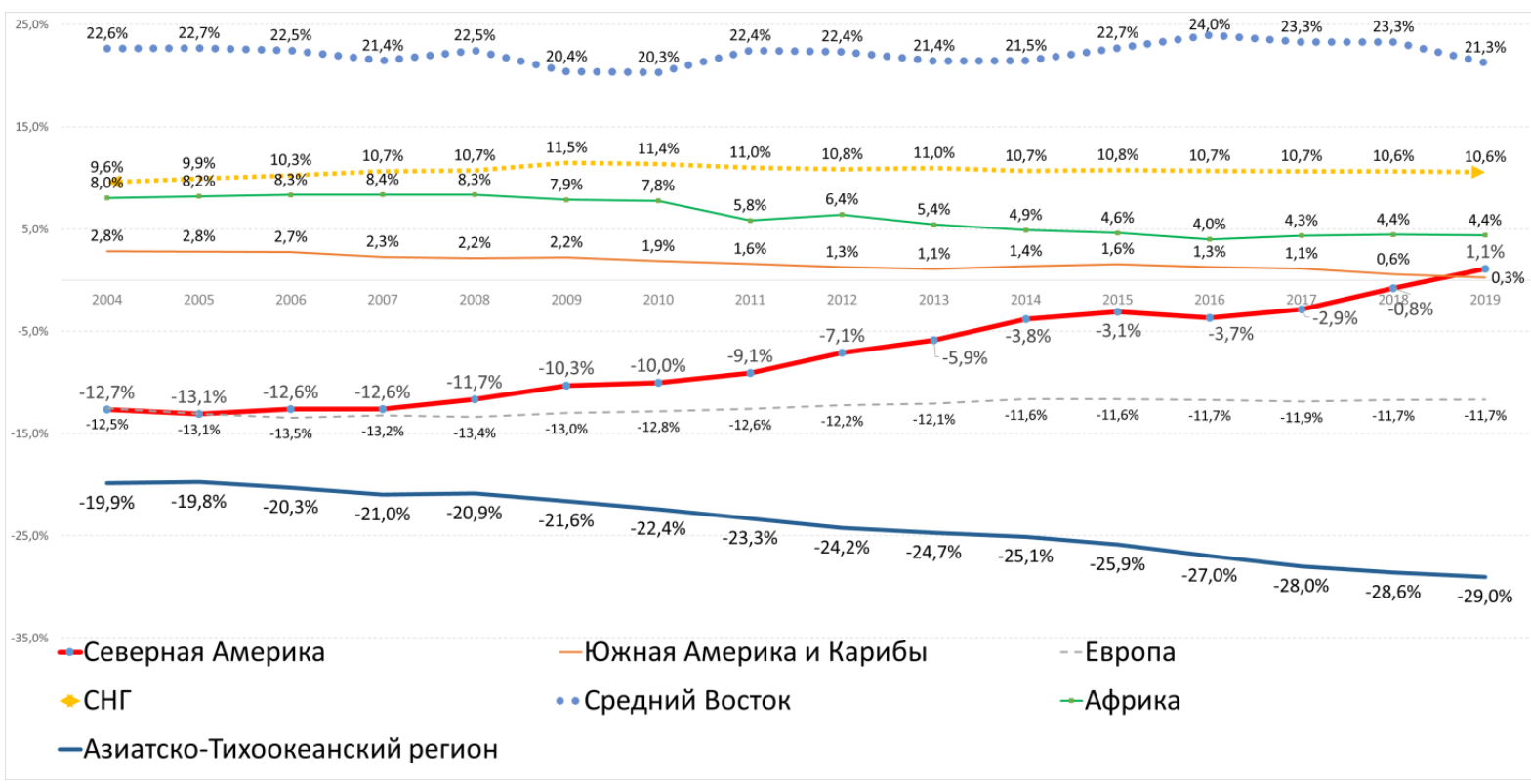

Pис. 2. Баланс добычи и потребления нефти по макрорегионам мира c 2004 no 2019 2., \%

Fig. 2. Region oil production and consumption balance 2004-2019

Более подробно влияние добычи «нетрадиционной» нефти можно увидеть в табл. 1. В США были внедрены технологии, позволяющие добывать нефть в сланцевых месторождениях. В результате нарастили добычу с 7,25 в 2004 г. до 17,04 млн баррелей ежедневно в 2019 г. Канада, использующая те же технологии, повысила добычу с 3,23 в 2004 г. до 5,65 млн баррелей ежедневно в 2019 г. Другие страны отказались от методов добычи нефти и газа на месторождениях, аналогичных с США и Канадой. Бразилия увеличила добычу нефти на шельфе. Уровень добычи вырос с 1,54 в 2004 г. до 2,88 млн баррелей ежедневно в 2019 г. Рост добычи нефти в Ираке можно назвать восстановительным после прошедшей в стране войны. Уровень добычи вырос с 2,03 в 2004 г. до 4,78 млн баррелей ежедневно в 2019 г. В других странах рост добычи происходил за счет традиционных месторождений. Причины сокращения добычи углеводородов не рассматриваются в данной статье. 
Таблица 2. Добыча и потребление нефти отдельными странами в 2004-2019 г2., млн баррелей ежедневно. Баланс между добычей и потреблением в 2004, 2019 г2., \% Table 2. Country oil production and consumption 2004-2019. Country oil production and consumption balance 2004, 2019

\begin{tabular}{|l|c|c|c|c|c|c|c|c|c|c|}
\hline & \multicolumn{4}{|c|}{ Добыча } & \multicolumn{4}{c|}{$\begin{array}{l}\text { Потребление } \\
\text { Mining }\end{array}$} & \multicolumn{3}{c|}{$\begin{array}{c}\text { Баланс } \\
\text { Balance }\end{array}$} \\
\cline { 2 - 14 } & 2004 & 2009 & 2014 & 2019 & 2004 & 2009 & 2014 & 2019 & 2004 & 2019 \\
\hline Канада/Canada & 3,23 & 3,33 & 4,42 & 5,65 & 2,31 & 2,18 & 2,39 & 2,40 & 1,11 & 3,31 \\
\hline США/USA & 7,25 & 7,27 & 11,80 & 17,04 & 20,50 & 18,03 & 18,14 & 19,40 & $-16,03$ & $-2,40$ \\
\hline Бразилия/Brazil & 1,54 & 2,02 & 2,34 & 2,88 & 1,85 & 2,08 & 2,72 & 2,40 & $-0,38$ & 0,49 \\
\hline $\begin{array}{l}\text { Российская Федерация } \\
\text { Russian Federation }\end{array}$ & 9,34 & 10,15 & 10,86 & 11,54 & 2,62 & 2,77 & 3,30 & 3,32 & 8,12 & 8,37 \\
\hline Иран/Iran & 4,22 & 4,28 & 3,71 & 3,53 & 1,50 & 1,92 & 1,90 & 2,02 & 3,29 & 1,54 \\
\hline Ирак/Iraq & 2,03 & 2,45 & 3,24 & 4,78 & 0,52 & 0,54 & 0,68 & 0,72 & 1,83 & 4,13 \\
\hline Кувейт/Kuwait & 2,52 & 2,50 & 3,11 & 3,00 & 0,37 & 0,45 & 0,46 & 0,43 & 2,60 & 2,61 \\
\hline $\begin{array}{l}\text { Саудовская Аравия } \\
\text { Sаudi Arabia }\end{array}$ & 10,31 & 9,71 & 11,52 & 11,83 & 2,06 & 2,91 & 3,76 & 3,79 & 9,98 & 8,19 \\
\hline ОАЭ/UAЕ & 2,82 & 2,79 & 3,60 & 4,00 & 0,49 & 0,61 & 0,88 & 1,04 & 2,83 & 3,01 \\
\hline КНР/РRС & 3,49 & 3,81 & 4,25 & 3,84 & 6,74 & 8,24 & 11,13 & 14,06 & $-3,93$ & $-10,40$ \\
\hline Индия/India & 0,78 & 0,84 & 0,91 & 0,83 & 2,60 & 3,30 & 3,91 & 5,27 & $-2,20$ & $-4,52$ \\
\hline
\end{tabular}

\section{Добыча и потребление природного газа}

Технологии добычи природного газа аналогичны технологиям добычи нефти. Зачастую добыча этих углеводородов происходит совместно, а разделяется уже на поверхности в специальных ёмкостях. Кроме того, транспортировка газа осуществляется почти так же, как и нефти: трубопроводным, морским и железнодорожным транспортом. Отличие только в том, что не нужно строить заводов по сжижению нефти, которые необходимы при использовании морского и железнодорожного транспорта. Из-за высоких затрат на сжижение газа или строительство трубопроводов на рынке газа сформировались межрегиональные перегородки, обуславливающие сегментарность мирового рынка газа. Так, в регионе Северная Америка при выборе между экспортом нефти или газа предпочтение даётся нефти, а газ потребляется внутри региона. Поэтому при построении следующего рисунка (рис. 3) важно было показать не баланс добычи и потребления газа изза высоких затрат на межрегиональные потоки, а динамику исключительно потребления газа регионами. В эффективности потребления первичных энергоресурсов предприятиями и населением газ проигрывает только электроэнергии.

На рис. 3 показана динамика потребления газа с 2000 по 2019 г. по следующим регионам: Северная Америка, объединённая в торговую ассоциацию НАФТА; АзиатскоТихоокеанский регион (далее - АТР); страны СНГ (без Украины); Средний Восток; Европейский регион (Европа без России и Белоруссии); Южная Америка и Карибские острова; Африка. Динамика потребления газа разнородная: есть лидеры - НАФТА (1057,6 млрд м $\left.{ }^{3}\right)$ и АТР $\left(869,9\right.$ млрд м $\left.{ }^{3}\right)$; аутсайдеры - Южная Америка и Карибы $\left(165,4\right.$ млрд м $\left.{ }^{3}\right)$, Африка (150,1 млрд м $\left.{ }^{3}\right)$; регионы со средним уровнем спроса на газ - страны СНГ $(573,7$ млрд $\left.\mathrm{m}^{3}\right)$, страны Среднего Востока $\left(558,4\right.$ млрд $\left.\mathrm{m}^{3}\right)$ и Европейский регион $\left(554,1\right.$ млрд м $\left.^{3}\right)$ [20]. Следует отметить кластеризацию регионов по потреблению газа к 2019 г. В 2000 г. не было такого чёткого разделения на группы, разница в потреблении с регионом ниже по иерархии была 100-150 млрд м $^{3}$. Регионы были более равномерно распределены по шкале.

Давая характеристику отдельным регионам, можно отметить следующее. Регион Северная Америка до 2009 г. не имел ускоренного роста потребления. В этот период 
спрос вырос всего на 15,9 млрд м ${ }^{3}$ (на 2 \%). После этого года рост ускорился: с 769,4 до 1057,6 млрд м ${ }^{3}$ в 2019 г. Прирост этого периода составил 288,2 млрд м ${ }^{3}$, или 27,3 \%. Сравнение представляется корректным из-за сравнительного равенства периодов.

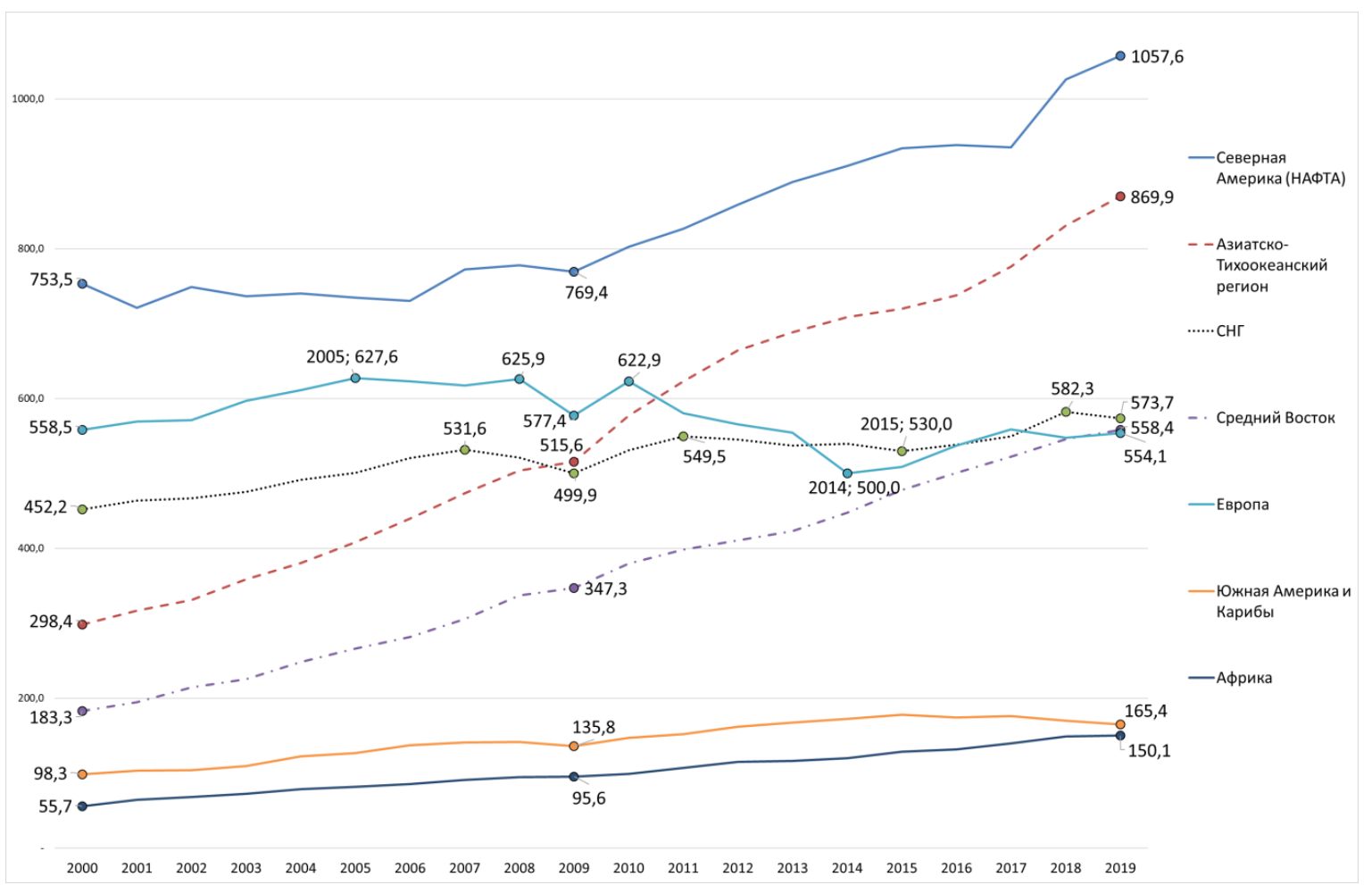

Pис. 3. Динамика потребления газа по макрорегионам мира (2004-2019), млрд м³

Fig. 3. Region natural gas consumption 2004-2019

Азиатско-Тихоокеанский регион является самым быстрорастущим на этом рынке. Если в 2000 г. он отставал от лидера на 455,1 млрд м ${ }^{3}$ (на 152,5 \%), то в 2019 г. разрыв сократился до 187,7 млрд м ${ }^{3}$ (на 21,6 \%). В 2009 г. значительного изменения в тренде роста спроса не происходило: в 2000-2009 гг. прирост 217,2 млрд м ${ }^{3}$, или 72,8 \%, в 2009-2019 гг. прирост 354,3 млрд м ${ }^{3}$, или 68,7\%.

Регион Средний Восток также быстрорастущий, хотя и отстает от АТР. Прирост потребления газа в 2000-2009 гг. 164,0 млрд м³, или 89,5\%, в 2009-2019 гг. прирост 211,1 млрд м ${ }^{3}$, или 60,8 \%. Здесь можно отметить, что Средний Восток догнал Европу, бывшую в 2000 г. на втором месте по объему потребления ресурса.

Европейская динамика потребления газа оказалась самой слабой из всех регионов. В 2019 г. потребление было меньше, чем в 2000 г. - соответственно 554,1 и 558,5 млрд м газа. При этом кривая потребления имела значительные колебания по годам: первый период - рост до 627,6 млрд м ${ }^{3}$ в 2005 г.; стагнация до 2007 г. - 625,9 млрд м³; спад в 2008 г. до 577,4 млрд м ${ }^{3}$; подъем до 622,9 млрд м ${ }^{3}$; плавный трёхлетний спад до 500,0 млрд м в 2014 г.; после этого пятилетка постепенного подъема до 554,1 млрд м². Таким образом, верхняя граница кривой определилась в диапазоне 622,9-627,6 млрд м $^{3}$, нижняя 500,0 млрд $\mathbf{m}^{3}$.

Кривая потребления газа стран СНГ во многом схожа с европейской кривой. Такая же волнообразная динамика: 2000 г. - 452,2 млрд м³; 2007 г. - 531,6 млрд м³; 2009 г. 499,9 млрд м м $^{3} 2011$ г. - 549,5 млрд м ${ }^{3} ; 2015$ г. - 530,0 млрд м ${ }^{3} ; 2018$ г. - 582,3 млрд м³ 2019 г. - 573,7 млрд м. 
Однако кластер аутсайдеров - Африка и Южная Америка с Карибскими островами - не является группой неудачников. Темпы роста заметно выше, чем у Европы и СНГ. В 2000-2019 гг. Африка увеличила потребление на 169,6 \%, Южная Америка и Карибские острова - на 68,2 \%, СНГ - на 26,9 \%, а Европа сократила потребление на 0,8 \%. Южная Америка и Карибы показали прирост потребления газа в 2000-2009 гг. 37,5 млрд м³ 38,1 \%, в 2009-2019 гг. прирост 29,5 млрд м ${ }^{3}$, или 21,7 \%. Африка показала прирост потребления газа в 2000-2009 гг. 39,9 млрд м $^{3}$, или $71,6 \%$, в 2009-2019 гг. прирост 54,6 млрд м ${ }^{3}$, или 57,1\%.

\section{Технологии получения энергии из «возобновляемых источников»}

В связи с тем, что возобновляемые источники энергии (далее - ВИЭ) способны вовлекать в экономический оборот незначительные величины (десятые доли процента) от потенциального объёма, то на первый план выходит стоимость энергии, производимой этими источниками. Интенсивная разработка и освоение промышленных технологий (ветроустановки, фотоэлектрические преобразователи, солнечные тепловые, геотермальные и биоэнергетические установки) дали возможность снизить стоимость энергии и биотоплива в разы. Академик В.Е. Фортов и д.т.н. О.С. Попель отметили динамику цен на ВИЭ с 1980 по 2005 г. [21]. Их данные были дополнены нами показателями из Отчета Международного агентства по возобновляемой энергии (IRENA) и REN21 [22]. По этим материалам составлена табл. 3.

таблица 3. Динамика цен на возобновляемые источники с 1980 по 2019 г., цент $/ \kappa B m^{*}$ ч [9]

Table 3. Prices on renewable energy 1980-2019 [9]

\begin{tabular}{|l|c|c|c|}
\hline \multicolumn{1}{|c|}{$\begin{array}{l}\text { Технология использования ВИЭ } \\
\text { Renewable energy technology }\end{array}$} & 1980 & 2005 & $2019 * *$ \\
\cline { 2 - 4 } & $100-125$ & $25-40$ & $15-36$ \\
\hline $\begin{array}{l}\text { Фотоэлектрические установки } \\
\text { Photovoltaic installations }\end{array}$ & $60-87$ & $15-17$ & $15-17$ \\
\hline $\begin{array}{l}\text { Teпловые coлнечные электростанции } \\
\text { Thermal solar power plants }\end{array}$ & $42-50$ & $4-5$ & $4-5$ \\
\hline Ветроустановки/Wind turbines & $11-14$ & $4-5$ & $4-5$ \\
\hline $\begin{array}{l}\text { Геотермальные энергоустановки } \\
\text { Geothermal power plants }\end{array}$ & $2,1-7 *$ & $1,9-4,7$ & - \\
\hline Биоэтанол/Bioethanol & & & \\
\hline
\end{tabular}

По таблице видно, что цены на ВИЭ резко упали в сравниваемых периодах. Подобная ценовая динамика вызвана, скорее всего, скоростью внедрения инноваций, опирающихся на значительные инвестиции во многих странах.

В отчете IRENA Global Renewables Outlook, Edition: 2020 [23] отмечается следующая динамика падения цен и роста производства ВИЭ. С 2010 по 2019 г. выровненная стоимость электроэнергии (LCOE) от солнечных фотоэлектрических батарей упала на 82 $\%$, достигнув 68,4 доллара США за мегаватт-час (МВтч), в то время как стоимость электроэнергии от берегового ветра снизилась на 45 \% до 52,8 доллара США/МВтч. За последние два года закупки солнечной энергии выросли на 44 \% во всем мире, достигнув 5,4 гигаватт (ГВт) в 2018 г. и 9,6 ГВт в 2019 г. С 2017 по 2018 г. почти половина всех аукционов солнечных фотоэлектрических батарей была проведена в Азиатско-Тихоокеанском регионе из-за высокого уровня солнечной радиации и падения стоимости технологии. Только Индия выделила на аукционы 17 ГВт солнечной фотоэлектрической мощности по средней цене 42,3 долл. США/МВтч. Аналогичным образом Китай установил 5 
ГВт солнечных фотоэлектрических батарей по средней цене 64,6 долл. США/МВтч, а заявки Филиппин на аукционе 50 МВт получены по цене всего 43,9 долл. США/МВтч [23].

Традиционная энергетика, опирающаяся на ископаемые органические энергоресурсы, с начала XXI в. в среднем в мире росла с темпом всего 1-1,5 \% в год, а технологии ВИЭ развивались средними темпами в десятки процентов в год (табл. 3). При этом абсолютным лидером роста стало производство электроэнергии с помощью фотоэлектрических энергоустановок: за 15 лет производство выросло в 241,2 раза. На втором месте оказались тепловые солнечные энергоустановки (с концентраторами) - рост в 15,5 раз. На третьем месте с небольшим отрывом идет производство электроэнергии с помощью ветроустановок - рост в 13,5 раз. Другие виды производства возобновляемых ресурсов, кроме электроэнергии, также показали чудеса роста: производство биодизеля выросло в 22,3 раза, этанола - в 4 раза. Использование солнечного света в качестве источника тепла и современное остекленение выросло в 8,5 раз. Полученные успехи по этим направлениям и новые инвестиции в них позволяют сделать позитивный прогноз в отношении описанных вариантов использования ВИЭ.

В результате основные показатели развития возобновляемой энергетики к 2019 г. достигли следующего уровня (табл. 4) [23]. В структуре производства явно преобладает гидроэнергетика - 44,4 \% (учтены давно используемые гидроэлектростанции).

Таблица 4. Показатели возобновляемой энергетики (2004-2019)

Table 4. Renewable energy consumption by technology: indicators and gains 2004-2019

\begin{tabular}{|c|c|c|c|c|c|c|}
\hline \multirow[t]{2}{*}{ Показатели/Indicators } & \multicolumn{3}{|c|}{$\begin{array}{l}\text { Выработка и мощность } \\
\text { Generation and power }\end{array}$} & \multicolumn{3}{|c|}{$\begin{array}{c}\text { Темпы роста, } \% \\
\text { Rates of growth, } \%\end{array}$} \\
\hline & 2004 & 2014 & 2019 & 2004-2012 & $2013-2019$ & 2004-2019 \\
\hline $\begin{array}{l}\text { Мощности установок возобновляемой } \\
\text { энергии, ГВт } \\
\text { Renewable energy installations capacity, } \\
\text { GW }\end{array}$ & 800 & 1712 & 2588 & 170,0 & 179,7 & 323,5 \\
\hline $\begin{array}{l}\text { Гидроэнергетические установки, ГВт } \\
\text { Hydropower plants, GW }\end{array}$ & 715 & 1055 & 1150 & 135,7 & 119,8 & 160,8 \\
\hline $\begin{array}{l}\text { Мощность биотопливных установок, ГВт } \\
\text { Capacity of biofuel plants, GW }\end{array}$ & $<36$ & 93 & 139 & 216,7 & 167,5 & 386,1 \\
\hline $\begin{array}{l}\text { Биотопливные установки, ежегодная ге- } \\
\text { нерация, ТВт*ч } \\
\text { Biofuel plants, annual generation, } \mathrm{TW}^{*} \mathrm{~h}\end{array}$ & 227 & 433 & 592,5 & 132,2 & 169,3 & 261,0 \\
\hline $\begin{array}{l}\text { Геотермальные энергоустановки, ГВт } \\
\text { Geothermal power plants, GW }\end{array}$ & 8,9 & 12,8 & 13,9 & 122,5 & 120,9 & 156,2 \\
\hline $\begin{array}{l}\text { Фотоэлектрические энергоустановки, ГВт } \\
\text { Photovoltaic power plants, GW }\end{array}$ & 2,6 & 177 & 627 & 2692,3 & 627,0 & 24115,4 \\
\hline $\begin{array}{l}\text { Тепловые солнечные энергоустановки } \\
\text { (с концентраторами), ГВт } \\
\text { Thermal solar power plants (with concen- } \\
\text { trators), GW }\end{array}$ & 0,4 & 4,4 & 6,2 & 450,0 & 248,0 & 1550,0 \\
\hline $\begin{array}{l}\text { Ветроустановки, ГВт } \\
\text { Wind turbines, GW }\end{array}$ & 48 & 370 & 651 & 495,8 & 230,0 & 1356,3 \\
\hline $\begin{array}{l}\text { Солнечные водонагревательные уста- } \\
\text { новки (с остекленением), ГВт } \\
\text { Solar water heating units (with glazing), GW }\end{array}$ & 86 & 406 & 731 & 269,8 & 259,2 & 850,0 \\
\hline $\begin{array}{l}\text { Производство этанола, млрд л } \\
\text { Ethanol production, billion liters }\end{array}$ & 28,5 & 94 & 114 & 302,1 & 138,0 & 400,0 \\
\hline $\begin{array}{l}\text { Производство биодизеля, млрд л } \\
\text { Biodiesel production, billion liters }\end{array}$ & 2,4 & 29,7 & 53,5 & 891,7 & 226,7 & 2229,2 \\
\hline
\end{tabular}


Суммарная мощность гидрогенерирующих электростанций - 1150 ГВт; выработка - около 4,306 ТВтч электроэнергии в год. При этом следует указать, что гидроаккумулирующие электростанции (далее - ГАЭС) в данном случае исключены из расчётов. Это не источники энергии, а средства её хранения. Наращивание мощностей ГАЭС играет важную роль в балансировании при выработке электроэнергии, в частности для переменных возобновляемых ресурсов. Ветряные электростанции заняли второе место по объёму выработки электричества - 25,2\%. Фотоэлектрические энергоустановки замыкают тройку лидеров, имея 24,2 \%. Все прочие источники смогли обеспечить только 6,2 \% вырабатываемой энергии.

\section{Вклад стран в производство возобновляемой электроэнергии}

В отчёте [22, с. 169] отмечается вклад каждой страны в общий объём выработки возобновляемой электроэнергии. Девять стран произвели 74,1 \% мирового производства, а три страны - КНР, США, ФРГ - 51,5 \% (рис. 4).

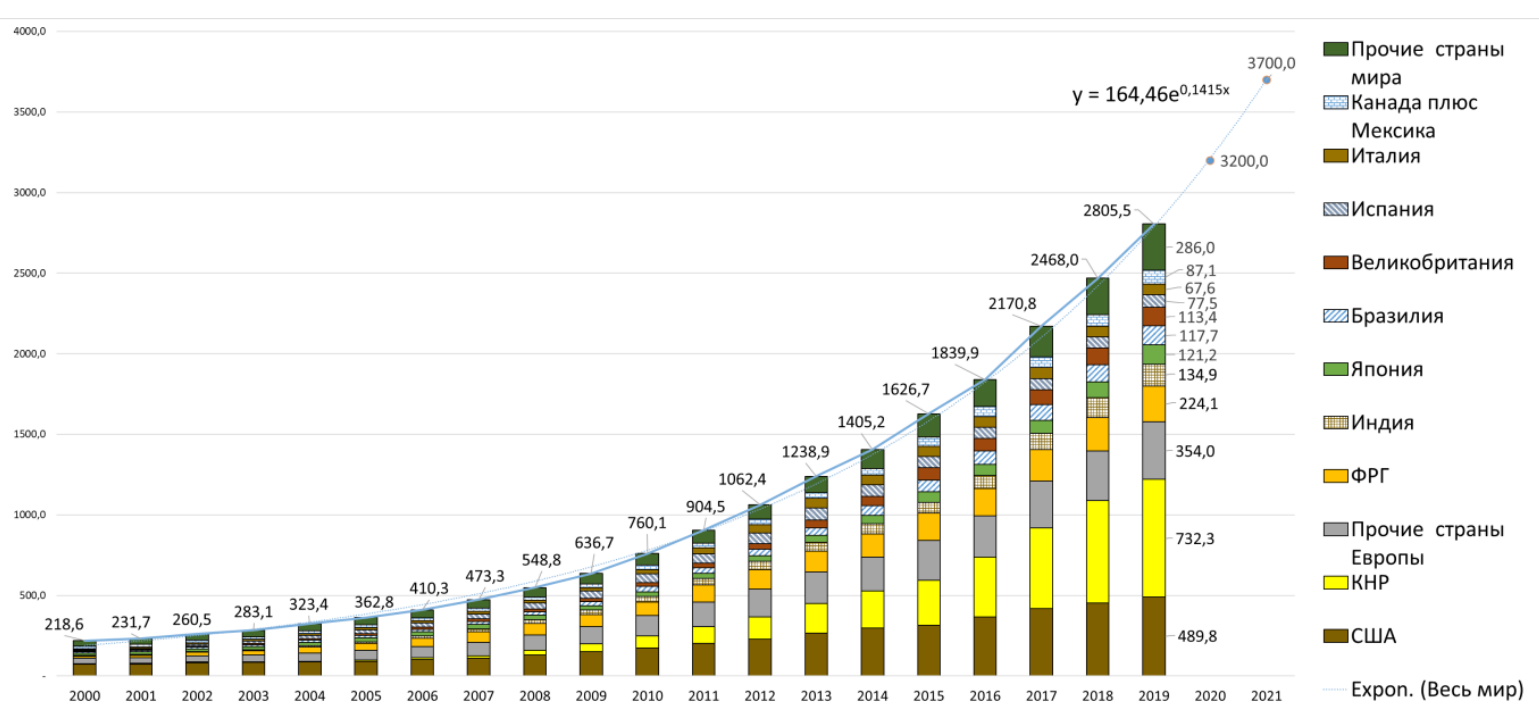

Pис. 4. Динамика использования возобновляемой электроэнергии: отдельно в КНР, Бразилии, Канаде и Мексике, США, Италии, Великобритании, Японии, Индии, ФРГ; отдельно прочие страны Европы; экспоненциальный тренд по странам мира, кроме 11 стран-лидеров (2000-2019), в ТВ*ч

Fig. 4. Country distribution of renewable energy consumption: China, Brazil, Canada and Mexico, US, Italy, United Kingdom, Japan, India, Germany, Other Europe, Exponential trend rest of World 2000-2019

По рисунку видно, что рост производства возобновляемой электроэнергии происходит по экспоненте. Формула экспоненты рассчитана нами: $y=164,46 e^{0,1415 x}$. Исходя из данной формулы, мы можем сделать прогноз на потребление ВИЭ на 2020, 2021 и последующие годы. В 2020 г. ожидаем производство на уровне 3200 ТВ·ч, в 2021 г. 3700 ТВ·ч.

Далее охарактеризуем структуру графика. Первоначальным лидером в начале 2000-х гг. были США (72,8 ТВ·ч). Однако уже с 2016 г. США (367,4 ТВ·ч) уступили первое место КНР (369,5 ТВ·ч). В 2019 г. КНР стала производить энергии этого вида в 1,5 раза больше, чем США (соответственно 732,3 и 489,8 ТВ·ч). На третьем месте - ФРГ, в 2019 г. произвела 224,1 ТВ·ч. В 2000 г. эта страна также была на третьем месте после 
США и Японии (соответственно 14,3, 72,8 и 16,6 ТВ·ч.). ФРГ обогнала Японию в 2002 г., заняв вторую позицию, которую продолжала удерживать до 2011 г. В 2012 г. ФРГ уступила это место поднимающейся КНР. При этом ФРГ продолжает производить ВИЭ больше Японии (в 1,8 раз за 2019 г.). Кроме того, ФРГ в 2000 г. уступала объединенной в североамериканскую систему Канаде с Мексикой (производили 15,6 ТВ·ч). Однако в 2019 г. ФРГ смогла производить энергии больше в 2,57 раз, чем эти две страны вместе.

Индия, так же как и КНР, стартовала с относительно низких позиций, чем другие страны списка лидеров. Индия в 2000 г. производила 3,3 ТВ·ч, КНР - 3,1 ТВ·ч. В 2006 г. Индия обогнала Великобританию и Италию, соответственно - 14,9; 13,5; 13,6 ТВ·ч. В следующем году она обошла Бразилию, соответственно 19,1 и 18,7 ТВ·ч. В 2016 г. Индия вышла на четвертое место, обогнав Японию, - соответственно 79,8 и 68,1 ТВ·ч.

В 2019 г. близко к Индии располагаются и могут её обогнать Япония, Бразилия и Великобритания. Показатели этих стран соответственно 134,9; 121,2; 117,7; 113,4 ТВ·ч.

\section{Выработка гидроэлектроэнергии}

Энергия падающей воды не использует ископаемое топливо в качестве сырья и не загрязняет окружающую среду выбросами парниковых газов. Поэтому отдельные эксперты относят гидроэнергетику к возобновляемым источникам энергии. Такая точка зрения присутствует, например, в IRENA. Другие исследователи не относят гидроэнергетику к ВИЭ. Во-первых, потому что гидроэлектростанции (ГЭС) начали строить за много десятилетий раньше, чем возникла необходимость устойчивого развития. Во-вторых, в результате строительства ГЭС происходят значительные экологические и геологические изменения в районах данного строительства. В-третьих, инвестиции в строительство ГЭС настолько значительны, что требуют решения государства, рыночный механизм дает сбои в производстве данного вида энергии. Поэтому мы будем рассматривать выработку гидроэлектроэнергии отдельно от ВИЭ.

В отчёте [20] указан вклад каждой страны в общий объём выработки энергии (рис. 5). В 2019 г. семь стран смогли произвести в два раза больше энергии, чем остальные страны мира. При этом доля КНР в этой группе семи стран составила 82,8 \%.

В первые два десятилетия XXI в. КНР выделяется также и по динамике роста выработки электроэнергии с 222,4 до 1269,7 ТВ·ч, или в 5,7 раз. Другие шесть стран-лидеров развивались медленнее. Их совокупное производство в этот период выросло с 1316,8 до 1533,9 ТВ·ч, или на $16,5 \%$.

Без сомнения, позиции стран внутри этой группы менялись. Например, выработка в Индии выросла с 77,0 до 161,8 ТВ·ч, или в 2,1 раза, в Бразилии - с 304,4 до 399,3 ТВ·ч, или на $31,2 \%$. В России выработка выросла практически на уровне среднего роста всей группы шести стран: на 18,5 \%, или с 164,1 до 194,4 ТВ·ч. Другие страны группы имели либо слабый рост, либо падение: Канада увеличила производство с 356,8 до 382,0 ТВ·ч, или на 7,1\%; США сократили с 272,8 до 271,2, или на 0,6 \%; Норвегия сократила с 141,8 до 125,3 ТВ·ч, или на 11,6 \%. Или вот в 2011 г. рекордные показатели выработки Бразилии - 428,3 ТВ·ч, США - 316,1 ТВ·ч. Но в другие годы производство было ниже.

Поэтому укажем производство электроэнергии (в скобках в долях от мирового производства) совокупно за эти двадцать лет: Канада - 7352,47 (10,9 \%), Бразилия - 7216,83 $(10,7 \%)$, США - 5328,69 (7,9 \%), Российская Федерация - 3463,74 (5,1 \%), Норвегия 2587,25 (3,8 \%), Индия - 2267,85 ТВ·ч (3,4 \%). В этом рейтинге Канада поменялась с Бразилией, а Индия с Норвегией. Но спустя пару лет может оказаться, что рейтинг выпуска за 2019 г. станет рейтингом за текущий год и в совокупности производства с 2000 г. 


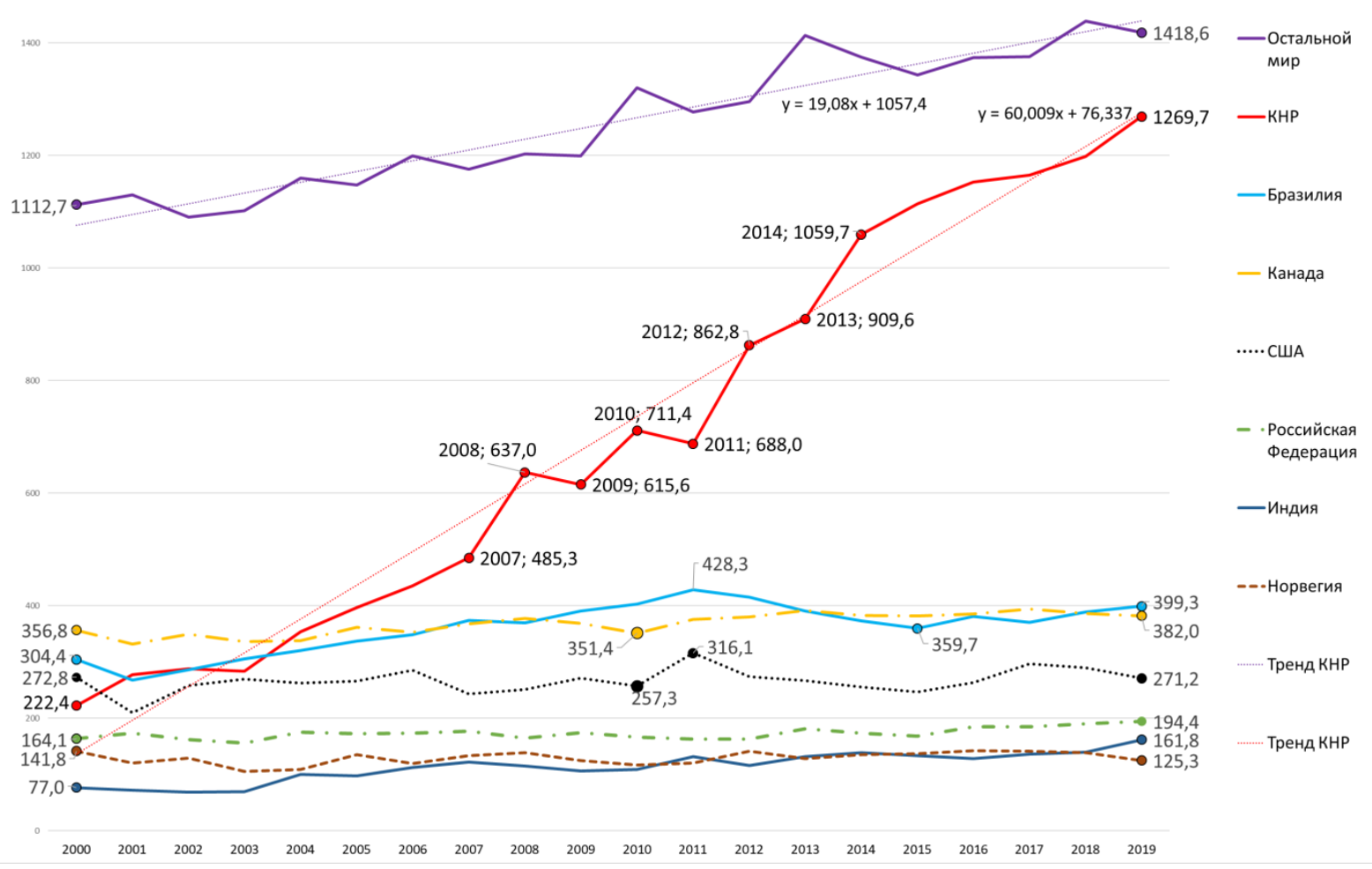

Pис. 5. Кривые выработки гидроэлектроэнергии с 2000 по 2019 г. в мире, кроме семи стран-лидеров (отдельно в КНР, Бразилии, Канаде, США, Российской Федерации, Индии, Норвегии), в ТВ`ч

Fig. 5. Country hydroelectricity consumption: rest of the World, China, Brazil, Canada, US, Russian Federation, India, Norway 2004-2019

Через пять лет может статься, что Турция выдавит Норвегию с седьмого места. Турецкая динамика (2,89 раза) превышает индийскую (2,1 раз), но меньше последней по объёму выработки: 30,9 (2000 г.) и 89,2 ТВ·ч (2019 г.). Японская, итальянская, французская, шведская, швейцарская меньше турецкой и не имеют той энергии роста, какая есть у Турции.

Однако эти темпы развития меркнут в сравнении с ростом в Китае. Повторюсь, выработка электроэнергии выросла с 222,4 до 1269,7 ТВ·ч, или в 5,7 раз. Развитие происходило ступенчато. Успешный рост 2008 г. на 151,3 ТВ·ч (31,3\%), сменился спадом, потом опять рост в 2010 г. на 95,8 ТВ·ч (15,6\%), затем опять спад и опять рост - в 2012 г. на 174,8 ТВ·ч $(25,4$ \%), после этого - только рост до 1269,7 ТВ·ч. За двадцать лет КНР выработала 14 128,64 ТВ·ч гидроэлектроэнергии, или 20,9 \% мирового производства.

\section{Производство атомной энергии}

Инвестиции в строительство атомных электростанций (далее - АЭС) требуют решения государства из-за своих размеров, рыночный механизм в производстве данного вида энергии не возможен в принципе, регулирование и надзор осуществляются на международном уровне. Поэтому динамика производства этого вида первичной энергии является функцией не только потребности в энергии, но и в политических возможностях страны (рис. 6).

На рис. 6 мы видим, что падает производство энергии в других странах, кроме пятерки лидеров. Четыре страны-лидера, если и увеличили производство, то 
незначительно. Ускоренный рост наблюдается только у КНР с 2014 г. - с 133,2 до 348,7 ТВ·ч, или в 2,6 раза. Отметим эти пять стран по выработке энергии в ТВ·ч и по удельному весу в мировом производстве: США - 852,0, 30,5 \%; Франция - 399,4, 14,3 \%; КНР $348,7,12,5$ \%; Российская Федерация - 209,0, 7,5 \%; Южная Корея - 146,0, 5,2 \%.

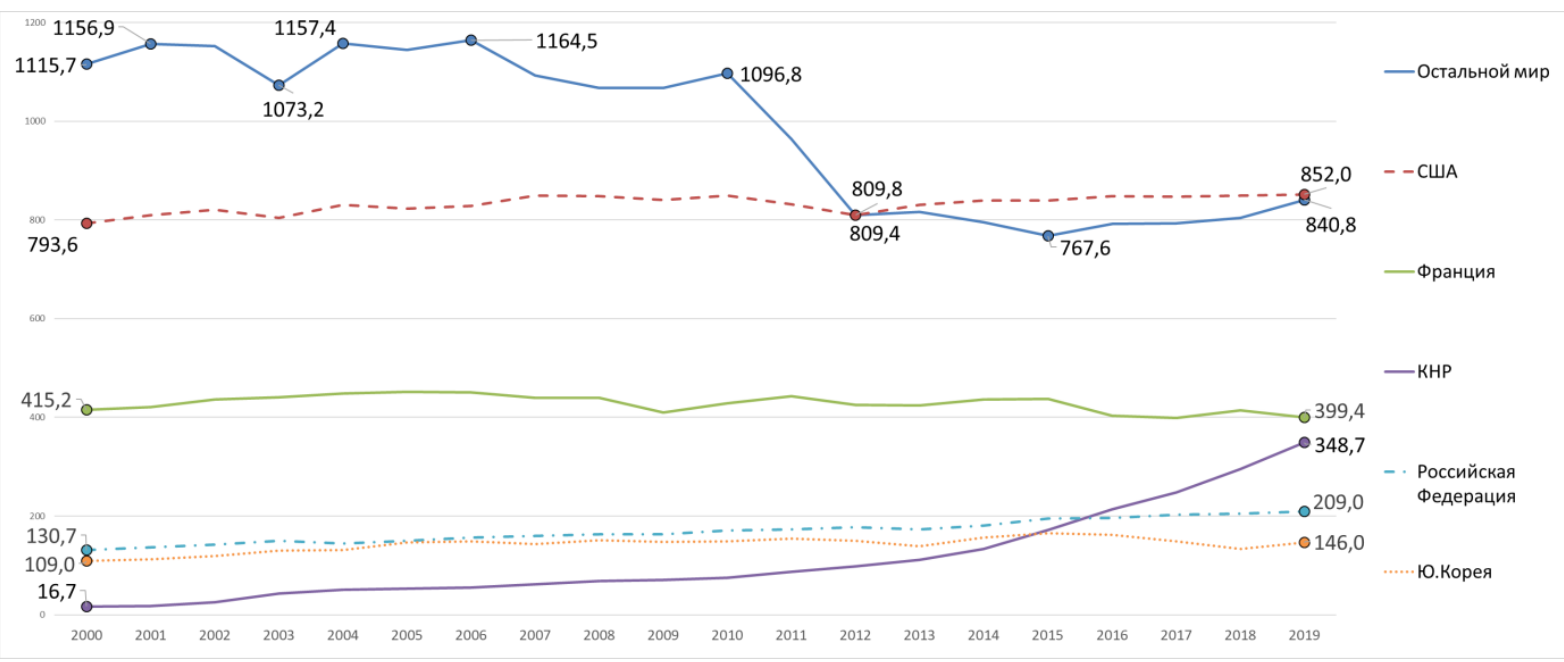

Puc. 6. Кривые производства атомной энергии с 2000 по 2019 г. в США; Франции; КНР; Российской Федерации; Южной Кореи, в прочих странах мира; в ТВ‘ч

Fig. 6. Country nuclear consumption: rest of the World, US, France, China, Russian Federation, South Korea 2000-2019

Выделим критерии, по которым были определены пять стран-лидеров: актуальный уровень производства (в 2019 г.), значительный вклад в мировой объем, относительно большая разница со страной, которая может догнать аутсайдера группы стран-лидеров. Из-за последнего критерия (малый удельный вес) не вошли Канада $(3,6 \%)$, Украина $(3,0$ \%), ФРГ (2,7 \%), Швеция (2,4 \%), Япония (2,3 \%), Испания (2,1\%), Великобритания $(2,0 \%)$ и другие страны. По первому критерию (уровень производства в 2019 г.) выпали из лидеров Япония, которая ранее, в 2010 гг., вырабатывала 292,4 ТВ·ч, или 10,6 \% мирового производства и обгоняла ФРГ (140,6 ТВ·ч, или 5,1 \%); Россию (170,4 ТВ·ч, или 6,2%); Южную Корею (148,6 ТВ·ч, или 5,4%). Но авария на станции Фукусима-2 и остановка аналогичных реакторов исключили как Японию, так и ФРГ из числа лидеров. В результате влияние атомной энергии сравнялось с влиянием ВИЭ.

\section{Потребление угля}

В целях борьбы с потеплением климата было принято решение сократить использование угля как топлива. Считается, что шесть газов могут стимулировать парниковый эффект, приводящий к глобальному потеплению климата, что, в свою очередь, грозит ростом стихийных бедствий в мире. Эти шесть газов перечислены в прил. А к Протоколу, принятому в г. Киото 11.12.1997, который опирается на Рамочную конвенцию ООН об изменении климата 1992 г. (РКИК ООН): углекислый газ $\left(\mathrm{CO}_{2}\right)$, метан $\left(\mathrm{CH}_{4}\right)$, оксид диазота $\left(\mathrm{N}_{2} \mathrm{O}\right)$, гидрофторуглероды (ГФУ), перфторуглероды (ПФУ) и гексафторид серы $\left(\mathrm{SF}_{6}\right)$. Киотский протокол вступил в силу 16.02.2005. Однако США, подписав этот протокол, не стали его ратифицировать и исполнять. Канада вышла из него в 2012 г., Индия и КНР не брали на себя обязательств по этому протоколу. Тем не менее большая часть стран ограничивает использование угля в качестве топлива. В связи с этим представляет 
интерес процесс отказа или неотказа стран от угля в качестве топлива. Согласно отчетам Бритиш петролеум, с 1965 г. доля угля в глобальной структуре потребления первичной энергии снижалась: с 37,6 \% в 1965 г. до 26,2 \% в 1978 г. После этого колебания происходили в рамках от 25,5 \% до 30,5\%. Минимум наблюдался в 2001 г., а максимум - в 2011 г. Динамика потребления угля в абсолютных величинах показана на рис. 7 [20].

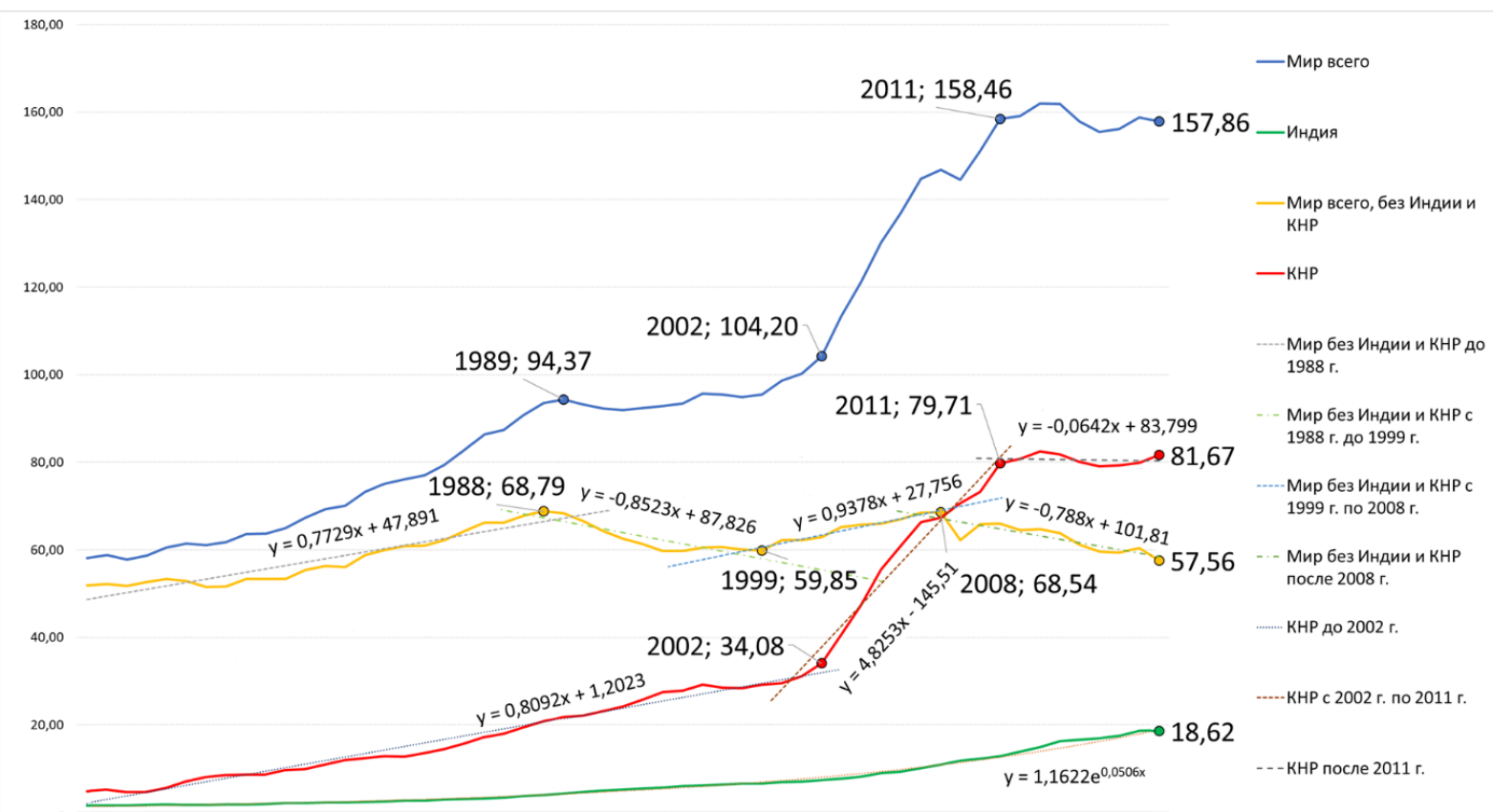

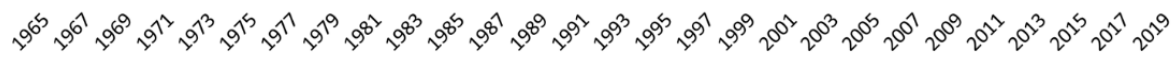

Рис. 7. Кривые потребления угля с 1965 по 2019 г. в мире всего;

в мире, кроме Индии и КНР; отдельно в КНР, Индии, в экзаджоулях

Fig. 7. Country coal consumption: total world, India, other world regions except for India and China, China 1965-2019

На данном рисунке показана динамика потребления угля по четырем видам выборки: все страны мира; все страны, кроме Индии и КНР; отдельно КНР и Индия. Кривую потребления угля всеми странами можно условно разделить на четыре участка: первый - с 1965 по 1989 г. (прирост 2,0 \% ежегодно), второй - с 1989 по 2002 г. (прирост 0,7\% ежегодно), третий - 2002 по 2011 г. (прирост 4,3\% ежегодно), четвертый - с 2011 по 2019 гг. (снижение на 0,04 \% ежегодно). Естественно, возникает вопрос: почему кривая так резко меняется? На следующей кривой из общемирового потребления были исключены самые крупные потребители - КНР и Индия. Форма этой кривой сразу изменилась. Заметны два пика - в 1988 (68,79 ЭДж) и 2008 гг. (68,54 ЭДж), а также минимумы - в 1965 (51,83 ЭДж), 1999 (59,85 ЭДж) и 2019 гг. (57,56 ЭДж). Если построить линейную линию тренда на этих участках, то можно увидеть некоторую близость наклонов первого и третьего участков: $y=0,7729 x$ и $y=0,9378 x$ соответственно. Квадратный корень этих двух чисел показал разницу всего в 10 \% между наклонами линий трендов. Наклоны второго и четвертого участков также имеют определенную близость: $y=-0,8523 x$ и $y=-0,788 x$ соответственно. Квадратный корень двух чисел показал разницу всего в 4 \% между наклонами линий трендов. Объяснение похожести в изменении трендов потребления угля требует дополнительного анализа энергетической политики стран мира. 
В рамках данной статьи отметим лишь поворотные точки и схожесть трендов в определенные периоды.

Следующая кривая в нашем анализе - кривая потребления угля Китаем. Отметим, что доля КНР составляет почти 52 \% мирового потребления угля, что указывает на значимость принятия решений данной страны в рамках мира. Однако такая ситуация была не всегда. В 1965 г. доля КНР была 8,2 \% мирового спроса на уголь. Рост потребления угля укладывался в рамки мирового потребления: $y=0,8092 x$ и $y=0,7729 x$ соответственно. Квадратный корень этих чисел показал разницу всего в 2,3 \% между наклонами линий трендов. Для большинства стран этот тренд закончился в 1988 г. и перешел в ниспадающий. В КНР данный тренд продолжался на четыре года больше - до 2002 г., но закончился трендом на резкий рост потребления $(y=4,8253 x)$. Такая динамика не прекращалась, пока КНР не достиг уровня в половину мирового потребления угля (2011). Даже после этого КНР не смогла сократить потребление угля, как это сделал остальной мир. Темпы снижения спроса на уголь были всего $y=-0,0642 x$, или в 11 раз меньше, чем у остальных стран (без Индии).

Кривая потребления угля Индией показывает, что страна заняла второе место только в 2015 г., обогнав США. Доля Индии составляет 11,8 \% от мирового потребления угля. Кроме того, если КНР зафиксировала уровень использования угля, США снизила, то Индия, наоборот, наращивает покупки угля по экспоненте $y=1,1622 e^{0,0506 x}$. Таким образом, роль Индии в спросе на уголь вырастет в ближайшей перспективе.

\section{Выводы}

1. В динамике цен на нефть наблюдается определенная цикличность. Границы циклов определяются по минимальным уровням цен, достигнутым после их резкого падения. В течение двух десятилетий XXI в. таких циклов можно насчитать не меньше четырех. Первый цикл закончился в декабре 2008 г. Цена упала в 3,5 раза до 40,11 долл. США. Второй спад произошел во второй половине 2014 г. со 112,5 до 49,15 долл. США, или в 2,3 раза. Третий спад длился до января 2016 г.: с 66,78 до 34,73 долл. США, или в 1,9 раза. Четвертый спад - с декабря 2019 по апрель 2020 г. Падение цен с 66,0 до 25,27 долл. США, или в 2,6 раза.

2. Построены два прогноза. Прогноз № 1 (оптимистический) - к февралю 2021 г. можно ожидать цены выше 60 долл. США за баррель с возможным коридором цен от 60 до 80 долл. США за баррель. Прогноз № 2 (пессимистический) - падение цен к январю 2021 г. до 21 долл. США за баррель и продолжительные колебания цен в диапазоне 20-35 долл. США за баррель.

3. При изучении баланса между добычей и потреблением нефти по регионам мира отмечены изменения по двум регионам: Северная Америка и Азиатско-Тихоокеанский регион. Прочие регионы имели колебания балансов в пределах двух процентов. Североамериканский регион к 2019 г. смог достичь самообеспеченности добываемой нефти (добыча больше потребления на 1,1 \% мирового потребления). В 2004 г. уровень потребления превышал уровень добычи на 12,7-13,1 \% мирового потребления. На тот период времени это соответствовало европейскому уровню. Европейский регион за эти 15 лет смог сократить эту разницу только на $1 \%$ - до 11,7 \%. Успех Северной Америки связан с ростом добычи «нетрадиционной» нефти в сланцевых месторождениях. Отказ европейских стран от такой нефти связан с экологическими требованиями, принятыми в этих странах. Азиатско-Тихоокеанский регион значительно увеличил потребление по отношению к добыче: с 19,9 \% в 2004 г. до 29,0 \% в 2019 г., что обусловлено стремлением сохранить высокие темпы экономического роста. 
4. Лидерами в потреблении газа является Северная Америка (1057,6 млрд м³) и АТР $\left(869,9\right.$ млрд м $\left.{ }^{3}\right)$; аутсайдеры - Южная Америка и Карибы $\left(165,4\right.$ млрд м $\left.^{3}\right)$, Африка $\left(150,1\right.$ млрд м $\left.^{3}\right)$; регионы со средним уровнем спроса на газ - страны СНГ $\left(573,7\right.$ млрд $\left.\mathrm{M}^{3}\right)$, страны Среднего Востока $\left(558,4\right.$ млрд $\left.{ }^{3}\right)$ и Европейский регион $\left(554,1\right.$ млрд м $\left.{ }^{3}\right)$. В 2009 г. наблюдался спад потребления по всем регионам, кроме Среднего Востока и Африки. Этот год для многих регионов был также переломным в трендах потребления газа. Поэтому период 2000-2019 гг. разбит на два подпериода: 2000-2009 гг. и 2009-2019 гг. Прирост потребления в млрд м³ показан соответственно этим двум подпериодам (в скобках указан темп прироста): Северная Америка - 15,9 (на $2 \%$ ) и 288,2 (на 27,3 \%); АТP - 217,2 (на 72,8 \%) и 354,3 (на 68,7 \%); Средний Восток - 164,0 (на 89,5 \%) и 211,1 (на 60,8 \%); Европейский регион - 18,9 (на 3,4 \%) и минус 23,3 (на -4,0 \%); СНГ - 47,7 (на 10,5 \%) и 73,8 (на 14,8 \%); Южная Америка и Карибы - 37,5 (на 38,1 \%) и 29,5 (на 21,7\%); Африка - 39,9 (на $71,6 \%$ и и 54,6 (на $57,1 \%)$.

5. Успех развития возобновляемой энергетики. По уровню производства этот вид первичной энергии в 2019 г. сравнялся с атомной энергетикой. В изучаемый период (2004-2019) больше всего увеличилось производство на фотоэлектрических энергоустановках (241,2 раз). На втором месте оказались тепловые солнечные энергоустановки (с концентраторами) - рост в 15,5 раз. На третьем месте, с небольшим отрывом, - производство электроэнергии с помощью ветроустановок - рост в 13,5 раз. Другие виды производства возобновляемых ресурсов, кроме электроэнергии, тоже показывали чудеса роста - производство биодизеля выросло в 22,3 раза, этанола - в 4 раза. Использование солнечного света в качестве источника тепла и современное остекленение выросли в 8,5 раз. Рост производства возобновляемой электроэнергии происходит по экспоненте, формула которой $y=164,46 e^{0,1415 x}$.

6. В общем объёме выработки возобновляемой электроэнергии удельный вес девяти стран составил 74,1 \% мирового производства, а трёх стран - КНР, США, ФРГ 51,5 \%. В 2019 г. КНР стала производить этот вид энергии в 1,5 раза больше, чем США (соответственно - 732,3 и 489,8 ТВ*ч). На третьем месте - ФРГ, в 2019 г. $224,1 \mathrm{~TB}^{*}$ ч. На четвертом - Индия - 134,9 ТВ*ч. Близко к ней и могут её обогнать Япония, Бразилия и Великобритания. Показатели этих стран соответственно 121,2;

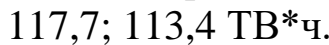

7. Пять стран-лидеров по выработке атомной энергии в $\mathrm{TB}^{*}$ и и по удельному весу в мировом производстве: США - 852,0; 30,5 \%; Франция - 399,4; 14,3 \%; КНР 348,$7 ; 12,5$ \%; Российская Федерация - 209,0; 7,5 \%; Южная Корея - 146,0; 5,2 \%. В период 2000-2019 гг. четыре страны-лидера, если и увеличили производство, то незначительно. Ускоренный рост наблюдается только у КНР с 2014 г. с 133,2 до $348,7 \mathrm{~TB}^{*}$, или в 2,6 раза. Авария на станции Фукусима- 2 и остановка аналогичных реакторов исключили как Японию, так и ФРГ из числа лидеров. Ранее, в 2010 г., Япония вырабатывала 292,4 ТВ*ч, или 10,6 \% мирового производства, и обгоняла ФРГ - 140,6 ТВ*ч, или 5,1 \%; Россию - 170,4 ТВ*ч, или 6,2 \%; Южную Корею - 148,6 ТВ*ч, или 5,4 \%. В 2019 г. Япония произвела 65,6 ТВ*ч атомной электроэнергии, или 2,3\%; ФРГ - 75,1 ТВ*ч, или 2,7\%.

8. При анализе потребления угля все мировые потребители были разделены на три группы: КНР, Индия и все остальные страны вместе взятые. Доля КНР составляет почти $52 \%$, Индии $-11,8 \%$ от мирового потребления угля. Остальные страны $36,2 \%$ от мирового потребления угля. Форма кривой потребления остальных стран 
имеет два пика - в 1988 (68,79 ЭДж) и 2008 гг. (68,54 ЭДж), а также минимумы - в 1965 (51,83 ЭДж), 1999 (59,85 ЭДж) и 2019 гг. (57,56 ЭДж). Линейная линия тренда на этих участках имеет близость (разница в $10 \%$ ) наклонов первого и третьего участков: $y=0,7729 x$ и $y=0,9378 x$ соответственно. Наклоны второго и четвертого участков также имеют определенную близость (разница в $4 \%$ ): $y=-0,8523 x$ и $y=-0,788 x$ соответственно. Кривая потребления угля КНР имеет три значимых участка: 1965-1988 гг. (наклон $y=0,8092 x)$; 1988-2002 гг. (наклон $y=4,8253 x$ ); 2002-2019 гг. (наклон $y=-0,0642 x)$. Кривая потребления угля Индии экспоненциальная: $y=1,1622 e^{0,0506 x}$.

Примечание. Перевод единиц измерения энергии: 1 т у.т. $=1,430$ т нефти (тнэ); 0,0293076 т у.т. $=1$ тераджоуль $\left(10^{12}\right.$ Дж); 1 экзаджоуль $=1 * 10^{18}$ Дж. В тонне нефти ко-

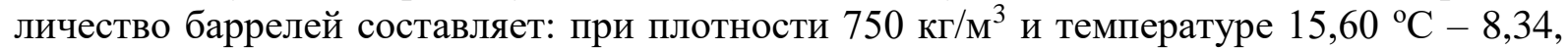
при плотности 800 кг/ $\mathrm{M}^{3}$ и температуре $15,60{ }^{\circ} \mathrm{C}-7,83$.

\section{СПИСОК ЛИТЕРАТУРЫ}

1. Цели в области устойчивого развития. URL: https://www.un.org/sustainabledevelopment/ru/sustainabledevelopment-goals/ (дата обращения 12.07.2020).

2. Цель 7: Обеспечение всеобщего доступа к недорогим, надежным, устойчивым и современным источникам энергии для всех // Цели в области устойчивого развития. URL: https://www.un.org/sustainabledevelopment/ru/energy/ (дата обращения 12.07.2020).

3. Цель 12: Обеспечение перехода к рациональным моделям потребления и производства // Цели в области устойчивого развития. URL: https://www.un.org/sustainabledevelopment/ru/sustainable-consumptionproduction/ (дата обращения 12.07.2020).

4. The Energy Progress Report 2020. URL: https://trackingsdg7.esmap.org/data/files/download-documents/tracking_sdg_7_2020-full_report_-_web_0.pdf (дата обращения 12.07.2020).

5. SDG12: Responsible consumption and production. Ensure responsible consumption and production patterns. URL: https://dm.pwc.com/SDGSelector/Resources/12.pdf (дата обращения 12.07.2020).

6. Башмаков И.А. Повышение энергоэффективности - главный энергетический pecypc. URL: cenef.ru/file/Study.ppt (дата обращения 12.07.2020).

7. Methodology. URL: https://www.bp.com/en/global/corporate/energy-economics/statistical-review-of-worldenergy/using-the-review/methodology.html\#accordion_primary-energy-methodology (дата обращения 12.07.2020).

8. Tracking SDG 7. The Energy Progress Report 2020. URL: https://webstore.iea.org/download/ direct/3004?fileName=Tracking_SDG7_The_Energy_Progress_Report_2020.pdf (дата обращения 12.07.2020).

9. Global Renewables Outlook: Energy transformation 2050. URL: https://www.irena.org//media/Files/IRENA/Agency/Publication/2020/Apr/IRENA_Global_Renewables_Outlook_2020.pdf (дата обращения 12.07.2020).

10. Энергетическая стратегия России на период до 2035 года (основные положения). URL: http://ac.gov.ru/files/content/1578/11-02-14-energostrategy-2035-pdf.pdf (дата обращения 12.07.2020).

11. Бушуев В., Куричев Н. Мировая энергетика'2050. Риски и возможности для России // Нефтегазовая вертикаль. URL: http://www.ngv.ru/upload/iblock/ed2/ed2b2edcd3dd6d15a0ce1b18b5bc909f.pdf (дата обращения 12.07.2020).

12. Динамика цены на нефть Брент (Brent). URL: https://www.calc.ru/dinamika-Brent.html (дата обращения 12.07.2020)

13. Вчера Россия объявила США и Саудовской Аравии нефтяную войну. URL: https://newsland.com/community/4765/content/vchera-rossiia-obiavila-ssha-i-saudovskoi-aravii-neftianuiuvoinu/7050437 (дата обращения 12.07.2020).

14. Основные прогнозные параметры сценариев Прогноза-2019 // Прогноз развития энергетики мира и России - 2019. URL: https://energy.skolkovo.ru/downloads/documents/SEneC/Research/ SKOLKOVO_EneC_Forecast_2019_Rus.pdf (дата обращения 12.07.2020).

15. Forecast Trading Economics. URL: https://tradingeconomics.com/commodity/crude-oil (дата обращения 12.07.2020). 
16. Государственная программа Российской Федерации «Развитие энергетики». URL: https://minenergo.gov.ru/node/323 (дата обращения 12.07.2020).

17. Грушевенко Е.В., Грушевенко Д.А. Сланцевая нефть: Технологии. Экономика. Экология // Экологический вестник России. - 2013. - № 5. - С. 21-26.

18. Гаранина О.Л. Перспективы добычи сланцевой нефти в США и последствия для мирового рынка нефти // Проблемы национальной стратегии. - № 4 (25). - 2014. - С. 185-204.

19. BP Statistical Review of World Energy June 2020. URL: https://www.bp.com/content/dam/bp/businesssites/en/global/corporate/xlsx/energy-economics/statistical-review/bp-stats-review-2020-all-data.xlsx (дата обращения 12.07.2020).

20. BP Statistical Review of World Energy 2020. 69th ed. URL: https://www.bp.com/content/dam/bp/ businesssites/en/global/corporate/pdfs/energy-economics/statistical-review/bp-stats-review-2020-full-report.pdf (дата обращения 12.07.2020).

21. Фортов B.Е., Попель О.С. Возобновляемые источники энергии в мире и в России. URL: http://www. reenfor.org/upload/files/77f24b05ec0fe4d2d44dbb6e666f1c7f.pdf (дата обращения 12.07.2020).

22. RENEWABLES 2019 GLOBAL STATUS REPORT URL: https://www.ren21.net/wp-content/uploads/2019/05/gsr_2020_full_report_en.pdf (дата обращения 12.07.2020).

23. IRENA_Global_Renewables_Outlook_2020. URL: https://www.irena.org/-/media/Files/IRENA/Agency/ Publication/2020/Apr/IRENA_Global_Renewables_Outlook_2020.pdf (дата обращения 12.07.2020).

Поступила 16.07.2020 г. 
UDC 338.465:621.31

\title{
GLOBAL PRIMARY ENERGY CONSUMPTION: THE MAIN TRENDS IN THE SECOND DECADE OF THE XXI CENTURY
}

\author{
Andrei A. Vazim 1,2 , \\ vazim@tpu.ru \\ ${ }^{1}$ Tomsk State University of Control Systems and Radioelectronics, \\ 40, Lenin avenue, Tomsk, 634050, Russia \\ 2 National Research Tomsk Polytechnic University, \\ 30, Lenin avenue, Tomsk, 634050, Russia
}

Andrei A. Vazim, Cand. Sc., associate professor, Tomsk State University of Control Systems and Radioelectronics; associate professor, National Research Tomsk Polytechnic University.

This article focuses on the analysis of trends to improve energy efficiency and meet the requirements of sustainable development. The aim of the research is to determine trends in the main characteristics of the energy market: price and quantity of demand. Consumption pattern of energy includes consumption of coal, crude oil and natural gas, petroleum products, electricity (such as renewable power generation, hydropower, nuclear power). Analysis and forecast of the prices were carried out only for oil of mark «Brent». Progress in access to energy and sustainable energy is analyzed by macroregions: North America, South America and the Caribbean, Asia-Pacific, CIS countries, the Middle East, the European region, and Africa. Method: forecast extrapolation based on the analysis of trends that determine the readiness of macroregions to abandon outdated and develop modern types of primary energy carriers; an analogy method for constructing a cyclical model of oil prices. Results. Four cycles of oil price dynamics in the first two decades of the XXI century are identified and characterized. Two variants of price levels for 2020-2021 are predicted. The main trends in primary energy consumption are described separately for each type and for each region of the world.

Key words: World energy, oil price forecasting, primary energy carriers, unconventional oil resources, renewable energy sources, sustainable development.

\section{REFERENCES}

1. Tseli v oblasti ustoychivogo razvitiya [Sustainable development goals]. Available at: https://www.un.org/sustainabledevelopment/ru/sustainable-development-goals/ (accessed 12 July 2020).

2. Tsel 7: Obespechenie vseobshchego dostupa k nedorogim, nadezhnym, ustoychivym i sovremennym istochnikam energii dlya vsekh [Goal 7: Ensure universal access to affordable, reliable, sustainable and modern energy for all]. Tseli $v$ oblasti ustoychivogo razvitiya [Sustainable Development Goals]. Available at: https://www.un.org/sustainabledevelopment/ru/energy/ (accessed 12 July 2020).

3. Tsel 12: Obespechenie perekhoda $\mathrm{k}$ ratsionalnym modelyam potrebleniya i proizvodstva [Goal 12: Ensuring the transition to sustainable consumption and production]. Tseli v oblasti ustoychivogo razvitiya [Sustainable Development Goals]. Available at: https://www.un.org/sustainabledevelopment/ru/sustainable-consumptionproduction/ (accessed 12 July 2020).

4. The Energy Progress Report 2020. Available at: https://trackingsdg7.esmap.org/data/files/download-documents/tracking_sdg_7_2020-full_report_-_web_0.pdf (accessed: 12 July 2020).

5. SDG12: Responsible consumption and production. Ensure responsible consumption and production patterns. Available at: https://dm.pwc.com/SDGSelector/Resources/12.pdf (accessed: 12 July 2020).

6. Bashmakov I.A. Povyshenie energoeffektivnosti - glavny energeticheskiy resurs [Improving Energy Efficiency is the Main Energy Resource]. Available at: cenef.ru/file/Study.ppt (accessed 12 July 2020). 
7. Methodology. Available at: https:/www.bp.com/en/global/corporate/energy-economics/statistical-review-ofworld-energy/using-the-review/methodology.html\#accordion_primary-energy-methodology (accessed: 12 July 2020).

8. Tracking SDG 7. The Energy Progress Report 2020. Available at: https://webstore.iea.org/download/ direct/3004?fileName=Tracking_SDG7_The_Energy_Progress_Report_2020.pdf (accessed: 12 July 2020).

9. Global Renewables Outlook: Energy transformation 2050. Available at: https://www.irena.org/-/media/Files/IRENA/Agency/Publication/2020/Apr/IRENA_Global_Renewables_Outlook_2020.pdf (accessed: 12 July 2020).

10. Energeticheskaya strategiya Rossii na period do 2035 goda (osnovnyye polozheniya) [Russia's Energy strategy for the period up to 2035 (main provisions)]. Available at: http://ac.gov.ru/files/content/1578/11-02-14energostrategy-2035-pdf.pdf (accessed 12 July 2020).

11. Bushuev V., Kurichev N. Mirovaya energetika'2050. Riski i vozmozhnosti dlya Rossii [World energy '2050. Risks and opportunities for Russia]. Neftegazovaya vertical. Available at: http://www.ngv.ru/ upload/iblock/ed2/ed2b2edcd3dd6d15a0ce1b18b5bc909f.pdf (accessed 12 July 2020).

12. Dinamika tseny na neft Brent (Brent) [Brent oil prices (Brent)]. Available at: https://www.calc.ru/dinamikaBrent.html (accessed 12 July 2020).

13. Vchera Rossiya obyavila SShA i Saudovskoy Aravii neftyanuyu voynu [Yesterday Russia declared an oil war on the United States and Saudi Arabia]. Available at: https://newsland.com/community/4765/content/ vcherarossiia-obiavila-ssha-i-saudovskoi-aravii-neftianuiu-voinu/7050437 (accessed 12 July 2020).

14. Osnovnye prognoznye parametry stsenariyev Prognoza-2019 [Main forecast parameters of Forecast scenarios-2019]. Prognoz razvitiya energetiki mira i Rossii-2019 [World and Russian energy development Forecast 2019]. Available at: https://energy.skolkovo.ru/downloads/documents/SEneC/Research/ SKOLKOVO_EneC_Forecast_2019_Rus.pdf (accessed 12 July 2020).

15. Forecast Trading Economics. Available at: https://tradingeconomics.com/commodity/crude-oil (accessed: 12 July 2020)

16. Gosudarstvennaya programma Rossiyskoy Federatsii «Razvitiye energetiki» [State program of the Russian Federation «Energy Development»]. Available at: https://minenergo.gov.ru/node/323 (accessed 12 July 2020).

17. Grushovenko E.V., Grushovenko D.A. Slantsevaya neft: Tekhnologii. Ekonomika. Ekologiya. [Shale oil Technology. Economy. Ecology]. Ekologicheskiy vestnik Rossii, 2013, no. 5, pp. 21-26.

18. Garanina O.L. Perspektivy dobychi slantsevoy nefti v SShA i posledstviya dlya mirovogo rynka nefti [Prospects of shale oil production in the USA and consequences for the world oil market]. Problemy natsionalnoy strategii, 2014, no. 4 (25), pp. 185-204.

19. BP Statistical Review of World Energy June 2020. Available at: https://www.bp.com/content/dam/bp/ business-sites/en/global/corporate/xlsx/energy-economics/statistical-review/bp-stats-review-2020-all-data.xlsx (accessed: 12 July 2020).

20. BP Statistical Review of World Energy 2020. $69^{\text {th }}$ ed. Available at: https://www.bp.com/content/dam/bp/ business-sites/en/global/corporate/pdfs/energy-economics/statistical-review/bp-stats-review-2020-full-report.pdf (accessed: 12 July 2020).

21. Fortov V.E., Popel O.S. Vozobnovlyayemye istochniki energii v mire iv Rossii [Renewable energy sources in the world and in Russia]. Available at: http://www.reenfor.org/upload/files/ 77f24b05ec0fe4d2d44dbb6e666f1c7f.pdf (accessed 12 July 2020).

22. RENEWABLES 2019 GLOBAL STATUS REPORT Available at: https://www.ren21.net/wp-content/uploads/2019/05/gsr_2020_full_report_en.pdf (accessed 12 July 2020).

23. IRENA_Global_Renewables_Outlook_2020. Available at: https://www.irena.org/-/media/Files/IRENA/Agency/Publication/2020/Apr/IRENA_Global_Renewables_Outlook_2020.pdf (accessed: 12 July 2020).

Received: 16 July 2020. 